\title{
THE MOTIF OF WRATH AND WITHDRAWAL IN MEDIEVAL EUROPEAN EPIC AND ITS IMPACT ON THE HOMERIC QUESTION - SOME PRELIMINARY REMARKS ${ }^{1}$
}

\author{
Peter Grossardt* \\ Recebido em: 06/05/2019 \\ Aprovado em: 20/05/2019
}

* University of Leipzig. grossardt@uni-leipzig.de

(i)

\begin{abstract}
Building on his research of 2009, the author of the following article will discuss some parallels to the wrath of Achilles in the medieval European tradition, especially in the Latin Song of Waltharius and in the French chanson de geste as exemplified most notably by the Geste de Fierabras. This epic forms the best parallel to the Iliad, but doesn't seem to depend on it. It is therefore claimed that the opening of the Iliad with the immediate conflict between the king and his main vassal represents a traditional device of oral epic poetry. As a consequence, the established idea of a chronographic epic style, which has been replaced by the more dramatic Homeric poems, has to be abandoned. On the contrary, it were the dramatic and colourful motifs like the wrath of Achilles or the conquest of Troy with the help of the Wooden Horse, which formed the kernel of the legend, around which smaller episodes crystallized that were told in a more chronographic style.
\end{abstract}

KEYWORDS: Homeric and international epic poetry; Achilles; wrath and withdrawal; medieval epic song; Song of Waltharius; Guillaume de Toulouse; Geste de Fierabras; Charlemagne and Roland.

$$
\begin{array}{r}
\text { LE SUJET DU RETRAIT EN COLÈRE DANS LA POÉSIE } \\
\text { ÉPIQUE EUROPÉENNE DU MOYEN AGGE ET } \\
\text { SON IMPORTANCE POUR LA QUESTION HOMÉRIQUE - } \\
\text { QUELQUES CONSIDÉRATIONS PRÉLIMINAIRES }
\end{array}
$$

\footnotetext{
${ }^{1}$ For help with the English resp. French language I am greatly indebted to Dr. J. Ronthaler (Leipzig) and Dr. C. Zubler (Fribourg).
} 
RÉSUMÉ: Reprenant ses recherches publiées en 2009, l'auteur du présent article discute quelques parallèles avec la colère d'Achille dans la tradition européenne médiévale, notamment dans la poésie latine avec Waltharius et dans la chanson de geste française, où l'accent est mis sur la Geste de Fierabras. Celle-ci représente le meilleur parallèle avec l'Iliade, tout en n'en étant probablement pas dérivée. L'auteur postule que le début de l'Iliade, avec le conflit direct entre le roi et son vassal principal, est donc un procédé traditionnel de la poésie épique orale. Par conséquent, il faut abandonner l'idée établie d'un style épique chronologique qui aurait été remplacé par l'épopée homérique, de forme plus dramatique. À l'inverse, ce sont les motifs dramatiques et pittoresques comme l'histoire de la colère d'Achille ou la conquête de Troie à l'aide du cheval de bois qui formaient le noyau original de la légende et les points de cristallisation sur lesquels se sont greffés par la suite des événements mineurs racontés dans un style plus chronologique.

MOTS-CLÉS: Poésie épique homérique et internationale; Achille; retrait en colère; poésie épique médiévale; Chanson de Waltharius; Guillaume de Toulouse; Geste de Fierabras; Charlemagne et Roland.

W

hen in 2009 the author of the present paper published his slim book on Achilles and Coriolanus, his ultimate goal was to reach a better understanding of the Iliad and its origin. ${ }^{2}$ That is, he tried to demonstrate with the help of comparative materials that behind the Homeric Iliad there was - as in the case of the Odyssey - an ageold tradition to tell the same story in roughly the same way. ${ }^{3}$ So, behind the Iliad there certainly was a tradition of telling the story of the Trojan War as a whole. But this doesn't mean that the way of telling was always - as is commonly assumed - chronographic and that only the poet of our Iliad chose to concentrate on the one short episode of Achilles' wrath and reconciliation in year ten of the war. ${ }^{4}$ Instead, there would have been an old tradition of focusing on this very episode, just as behind the Odyssey there probably was a poetical tradition to focus on the moment of Odysseus' homecoming and to tell the various adventures on his long journey as a flash-back or a comparatively short prologue. ${ }^{5}$

The comparative materials this argument was based on were mainly taken from other Indo-European epic traditions like Sanskrit epics, medieval Iranian traditions and nineteenthcentury Serbian songs. ${ }^{6}$ They all show heroes, who during a long war get offended by their king or his people, react with wrath and withdrawal and who only after humble pleas of their

\footnotetext{
${ }^{2}$ Grossardt, 2009.

${ }^{3}$ This conclusion has been denied as late as 2011 by W. Hansen (2011, p. 292: "Unlike the Odyssey, the Iliad is not constructed upon an international tale ..."), but it is precisely this point, which shall be proven, so far as possible, in the present paper.

${ }^{4}$ Most prominently stated by Kakridis, 1949, p. 91-93, Heubeck, 1974, p. 148 f., Kullmann, 1981, p. 41 f. and Latacz, 1985, p. 116.

${ }^{5}$ For the traditional nature of the shape of the Odyssey (and not just of its story-line) cf. Hölscher, 1989, p. 33 f. and Danek, 1996, esp. p. 16 and 19-21.

${ }^{6}$ The book was therefore polemizing as much against those who upheld that there are no such parallels (Reinhardt, 1961, p. 20; Erbse, 1983, p. 3; Griffin, 1995, p. 134) as against those who claimed that
} 
king and long negotiations are willing to reenter battle. The majority of these stories are indeed only of an episodic nature with respect to the story of the whole war or to the epic treating this particular motif. But at least one such epic, the Serbian song of Marko Kraljević, treats the motif as absolutely central for the story of the war and therefore heavily focuses on this very episode, just as the Iliad does. ${ }^{7}$ These 'eastern' stories in the book of 2009 were complemented by some 'western' stories which do not actually display the exact motif of wrath and withdrawal, but show considerable similarities and might indeed go back to this particular motif. These were the Roman story of the Old Republican hero Coriolanus and two famous medieval epic stories, the Spanish epic of El Cid and the Irish (prosimetric) epic Táin bó Cúalnge. They all indeed show a variant of the traditional conflict between rex and $d u x,{ }^{8}$ the precise form of the conflict depending, of course, on the respective historical situation and poetic tradition.

However, when writing this book and dealing with these traditions, it was not known to the author that there were other (western) medieval traditions, which indeed don't just show similarities with the story of Achilles and Agamemnon, but almost perfect parallels. ${ }^{9}$ These are the Latin epic of Waltharius and several songs in Old French. In what follows, the author will briefly present these stories and try to fit them into the overall picture. ${ }^{10} \mathrm{~A}$ final discussion will then try to show the impact on our central question of how the Iliad came to be. ${ }^{11}$

the motif of wrath and withdrawal was a common one, but never gave any evidence for their claim (Griffin, 1980, p. 6; Edwards, 2005, p. 304).

${ }^{7}$ The parallel between the Iliad and the song of Marko Kraljevic and Mina of Kostur has first been seen by Lord, 1969, p. 19 f. and p. 30 and Lord, 1972, p. 316 f. This observation has been questioned by Sauge, 2010, but cf. the counter-critique by Grossardt, 2015.

${ }^{8}$ The Latin terms are fittingly used for the general pattern by Nagy, 1979, p. 48 n. 3. But they can be found already for Agamemnon and Achilles in the Ilias Latina (vv. 58-61: exarsit subito violentia regis // ... // ... tum magnum incusat Achillem // inque vicem ducis invicti convicia suffert).

${ }^{9}$ The Song of Waltharius and the Geste de Fierabras had, however, been briefly discussed and compared with the Iliad in the pioneering work of V. Zhirmunsky (1961, p. 63; 1962, p. 133 f.).

${ }^{10}$ As this paper has been written not by a medievalist, but by a classicist and comparatist and as it is nevertheless directed as well to medievalists as to Homerists or classicists in general, the following procedure with respect to the various involved languages has been decided upon: Latin texts will remain untranslated. Greek texts will be referred to in the original and in an English translation. Vernacular texts of the Middle Ages will, however, be quoted in a modern form of the respective language, so Old French will be represented by Modern French, Old English by contemporary English and Middle High German by standard Modern German. Similarly, the Latinized names of the various Germanic or Aquitainian heroes in the Song of Waltharius have been kept throughout (e.g. 'Waltharius' and not 'Walther' or 'Waldere'), whereas the names of the many heroes of the Old French chansons de geste will appear in the form commonly used in modern French translations.

11 The paper will thus focus more on the diachronic aspect of the wrath of Achilles. For more synchronic treatments cf. Muellner, 1996 and Janda, 2018, for wrath on the divine level Considine, 1969. 


\section{THE LATIN SONG OF WALTHARIUS}

The Latin epic of Waltharius is a rather unique work of art combining Germanic lore with Christian faith and a highly developed culture of Latin poetry. ${ }^{12}$ It is therefore written in fine Latin hexameters, that are deeply embedded in classical Latin poetry, Vergil and Statius (among others) being the most prominent models for its phraseology. ${ }^{13}$ The origin of the epic continues to be debated among specialists. It may have been composed by the monk Ekkehard I in the monastery of St. Gall around the year $930 \mathrm{AD},{ }^{14}$ but it might as well have been written somewhere in Germany or in (eastern) France, perhaps as early as in the first half of the ninth century. ${ }^{15}$

The epic treats the story of the young Aquitainian hero Waltharius who already as a child had been given by his father, King Alpher, as a hostage to King Attila of Pannonia. Similarly Hagano (otherwise known as Hagen from the Song of the Nibelungen), a vassal of King Gibicho of Worms and later of Gibicho's son Guntharius, had been given as a hostage of the Franks, and the third to join was Hiltgunt, the daughter of King Heriricus of Burgundy and fiancée of Waltharius from early on. Although treated well by Attila the hostages suffer from homesickness and having reached maturity decide to flee from Pannonia, first Hagano and later Waltharius with Hiltgunt. Despite some difficulties they all manage to escape from Attila and his troops. But when Waltharius together with Hiltgunt crosses the river Rhine, he is recognized by the servants of Guntharius and soon is confronted with a financial request by the king who thinks that at least a part of Waltharius' riches belongs to him. Although Waltharius is willing to make compromises, no agreement is reached, and Waltharius therefore in the Vosges Mountains has to defend his life and his treasures in an armed showdown against a series of twelve Frankish warriors. Finally, in a single combat between Waltharius on the one side and Guntharius and Hagano on the other side the battle ends with a draw (and serious wounds for every one participant of this last fight), and Waltharius is at last allowed to travel home to Aquitaine, to marry Hiltgunt, and to start a long prosperous reign.

This rather straightforward story of about 1450 Latin lines doesn't stand alone, but is paralleled by fragments and short summaries in several vernacular languages, which testify to an ample Germanic tradition of the story. The relation between the Latin poem and the vernacular tradition is not entirely clear, and it has even been claimed by Friedrich Panzer in 1948 that Waltharius is an original creation and that all other witnesses depend on it. This

\footnotetext{
${ }^{12}$ This particular blend was certainly due to the poem not being addressed at an aristocratic audience but rather at a monastic one. This feature also explains that the story of Waltharius and Hiltgunt is told here in a style rather different from the (fragmentary) Germanic texts that treated the same story; cf. Millet, 2014, p. 230 f.; Lienert, 2015, p. 78 and Rio, 2015, p. 45-47.

${ }^{13}$ For the many allusions in the text to classical Latin poetry cf. the apparatus fontium in the edition by Strecker, 1951 and the learned papers by Zwierlein, 1970 and Bisanti, 2002.

${ }^{14}$ This is the classical position of Jacob Grimm, still defended for example by K. B. Vollmann, in: Haug; Vollmann,1991, p. 1170-1176 and p. 1186 f. and by Ratkowitsch, 2016, p. 37 f.

${ }^{15}$ See the recent discussions by Fasbender, 2013, p. 10; Lienert, 2015, p. 72; Ring, 2016, p. 8-15 and Maclean, 2018, p. 228 f.
} 
theory, however, has been severely criticized by many other specialists ${ }^{16}$ and today can be considered to have been definitively refuted. ${ }^{17}$

The most interesting motif within the context of our study is the short episode immediately before the long series of combats. Hagano, who had already warned Guntharius beforehand not to engage in a fight with Waltharius, here for the second time dissuades his king from taking such a risk. But he gets severely rebuked by Guntharius who blames him for cowardice (v. 628-631). Hagano therefore gets angry and declares his withdrawal from battle (v. 632-639: tunc heros magnam iuste conceperat iram, / / si tamen in dominum licitum est irascier ullum. // 'en' ait '... // eventum videam nec consors sim spoliorum.' // ...). ${ }^{18}$ This is of course the classical motif of wrath and withdrawal, familiar to every classicist from the opening of the Iliad. Predictably, the abstention of Guntharius' strongest warrior leads to heavy devastation, with a long series of Frankish heroes being killed by Waltharius who defends himself in a narrow strait of the mountains in a long row of single combats. Not even the death of Patavrid, Hagano's nephew from his sister who fights as sixth in the row, moves Hagano to reenter battle. Therefore, after another five lethal combats Guntharius finally decides to make amends and in a series of three speeches manages to make Hagano change his mind (v. 1062-1129).

By a very happy coincidence the Song of Waltharius doesn't stand alone with respect to the motif of wrath and withdrawal. There are within the fragmentary vernacular tradition of the story even two excerpts showing a similar incident. These are the Old English Song of Waldere and a short digression in the Song of the Nibelungen.

The Old English epic of Waldere is difficult to date, but should be roughly contemporary with the Song of Waltharius and although perhaps being influenced by the Latin epic certainly represents an authentic Germanic tradition. ${ }^{19}$ The two preserved fragments of together about sixty lines show a series of speeches by the protagonists of the story. The most interesting passage for our discussion is a sentence by Waltharius (Waldere) within a speech addressed to Guntharius (Guðhere). After a long series of fights (apparently between Waltharius and the soldiers of Guntharius), the king had expected that now Hagano (Hagena) would enter battle and decide the fight. But this assumption turned out to be wrong and therefore Guntharius will now have to fight himself (II 14-16: "Behold, Lord of Burgundy! You really believed that Hagen would take a hand in your ambush and outflank me in this footwar." ${ }^{20}$ ). Hagano, at first a loyal vassal of Guntharius, therefore at some point shortly

\footnotetext{
${ }^{16}$ See for example the study of W. Regeniter, 1971, who on page 424 of his book even proposes a stemma that includes all the attested or hypothetical witnesses of the story, the Latin poem being just one testimony in a side branch of the entire tradition.

${ }^{17}$ See for example B. K. Vollmann, in: Haug; Vollmann, 1991, p. 1178 („,.. daß die These heute als erledigt gelten darf.“); Bornholdt, 2005, p. 43 f. or Ring, 2016, p. 7.

${ }^{18}$ Quoted from the edition of Strecker, 1951.

${ }^{19}$ Cf. Schwab, 1979, p. 350 and 364.

${ }^{20}$ Translated by Himes, 2009, p. 81, cf. the German translation by Schwab, 1979, p. 368 („Nun, du dachtest wirklich, Fürst der Burgunder, daß mir die Hand Hagens den Kampf besorgen und mich
} 
before the moment of our speeches must have left the battle-field. His reason for doing so is not stated. But given the pathetic character of our fragments it cannot have been something ludicrous like a hunting-accident or another such reason. Instead, his decision must rather have been a reaction to a conflict with Guntharius. The reason for this conflict is again not clear. It may have been a conflict of loyalties for Hagano, who anyway right from the beginning must have been torn between the loyalty for his king and the loyalty for his friend or even sworn-brother Waltharius. ${ }^{21}$ But Hagano may more specifically have been put off recently by Guntharius' greedy behaviour, ${ }^{22}$ or he may even have been offended by him, just as in the Song of Waltharius. ${ }^{23}$

The digression in the Song of the Nibelungen (str. 2344) is only one of several comparable flash-backs the heroes of the epic utter while being at the court of Attila. ${ }^{24}$ Here Hagano (Hagene) gets into an argument with Dietrich of Berne's vassal Hildebrand (Hildebrant). A short time before, they had even been engaged in a deadly fight over Hildebrand's nephew Wolfhart, and as the elderly Hildebrand was about to be killed by the much stronger Hagano, he fled from the hall of the court where the battle took place (str. 2307 f.). Hagano now taunts him for this act of cowardice (str. 2343), but Hildebrand replies by pointing to a similar incident in Hagano's earlier life (str. 2344: „Laßt solchen Vorwurf sein. // Wer saß auf seinem Schilde vor dem Wasgenstein, // da ihm der Spanier Walther so viele Freunde schlug? / / Wollt Ihr andrer spotten, man findet an Euch selbst genug. “25). This clearly alludes to the battle between Waltharius and Guntharius in the Vosges Mountains and to Hagano's withdrawing from figthting. ${ }^{26}$ But briefly mentioning a shield Hagano was sitting on while oberserving the battle, the Song of the Nibelungen gives an (enigmatic ${ }^{27}$ ) extra-element that cannot be found in the Song of Waltharius. The brief allusion therefore testifies to a vernacular tradition independent of the Latin poem. ${ }^{28}$ But as in the case of Waldere, it is not clear what actually made Hagano withdraw from fighting. Hildebrand insinuates that the reason

vom Fußkampf abhalten würde.").

${ }^{21}$ This conflict of loyalties has been identified as the main feature of the story by Mora-Lebrun, 1994, p. 161 f. and Blänsdorf, 2010, p. 86 f.

${ }^{22}$ Cf. Schwab, 1979, p. 242 f. and Himes, 2009, p. 44 and 69 f.

${ }^{23}$ As suggested by Regeniter, 1971, p. 273.

${ }^{24}$ The other digressions mentioning Waltharius' and Hagano's former stay in Pannonia are strr. 1756 and $1796 \mathrm{f}$. The epic is dated to around $1200 \mathrm{AD}$ (Lienert, 2015, p. 32).

${ }^{25}$ Translated by de Boor, 2003, p. 709.

${ }^{26} \mathrm{Cf}$. the corresponding scene in Waltharius, v. $638 \mathrm{f}$. (dixerat [sc. Hagano] et collem petiit mox ipse propinquum

// descendensque ab equo consedit et aspicit illo).

${ }^{27}$ That is, enigmatic to us, not to the original audience of the Song of the Nibelungen.

${ }^{28}$ As correctly concluded by Regeniter, 1971, p. 294 f. (the claim by Panzer, 1948, p. 52 f. and Ratkowitsch, 2016, p. 17 f., that the poet of the Song of the Nibelungen here follows Waltharius, therefore won't hold up). Such a conclusion about an independent vernacular tradition is anyway suggested by other Middle High German texts treating the story like the so-called Graz- and Vienna-fragments (edited by Learned, 1892, p. 65-72 and Strecker 1907, p. 100-109, translated into English by Magoun, Smyser, 1950, p. 43-47). See the detailed discussions of the two fragments by Schneider, 1925; Haug, 
was cowardice. But this may only be a retort to Hagano's unfair allegations immediately preceding. ${ }^{29}$ It is therefore quite possible that in the authentic Germanic tradition of the story there was the same motif of Guntharius offending Hagano and Hagano withdrawing from battle exactly as we have it in the Latin song.

There are thus basically two options: Either the motif of Hagano's wrath and withdrawal was part of an old tradition, which was adopted by the poet of the Latin Song of Waltharius, but was somewhat obscured - for whatever reasons - in the Waldere and in the Song of the Nibelungen, or there was an old tradition of Hagano withdrawing from battle - perhaps because of his former friendship with Waltharius - and only the Latin poet transformed this motif into a story of offence, wrath and withdrawal because of a personal conflict between Hagano and Guntharius. The question therefore arises, whether the Song of Waltharius couldn't depend on the Iliad..$^{30}$ The poet certainly was familiar with the legend of Troy (as basically everyone was in the Middle Ages), and this can be proven with his short remarks about the Trojan hero Pandarus, the ancestor of the Frankish warrior Werinhardus, in lines 727-729, ${ }^{31}$ which are almost literally taken from Verg. Aen. 5,495-497, where precisely the same information is given about Pandarus' role in the Trojan War. But as the Iliad itself was not known in the monastic culture of central Europe at the time, it is difficult to see, where exactly the poet of Waltharius would have gotten from his information about the wrath and withdrawal of Achilles. There are indeed some allusions to the story in the Aeneid. But these are clearly too short to give a precise idea about the way the story unfolds. ${ }^{32}$ It is a bit better with Ovid, who dedicates the complete letter of Her. 3 to the situation and apart from this gives a whole series of short allusions to the Trojan War and the central conflict between Achilles and Agamemnon. But Briseis' letter is a very subjective retelling of the story from a rather limited point of view, and it is the same with all the other brief mentionings in Ovid's love poetry or in his elegies from exile. ${ }^{33}$ The most widespread treatments of the legend of Troy in the medieval West were anyway the two novels by Dictys of Crete and Dares the

1997 and Göhler, 2003 and the more general remarks about the steady vernacular tradition of the story by Lienert, 2015, p. 78.

${ }^{29}$ In any event, the retort 'echoes' the reproach Guntharius had made to Hagano in the Song of Waltharius (v. 629-631) and Hagano's later sarcastic reply to this offence (v. 1067-1072).

${ }^{30}$ The question has hardly ever been asked by the specialists in the field, who all seem to assume that the motif of Hagano's wrath and withdrawal, like the rest of the main story-line, indeed was traditional Germanic lore (Schwab, 1979, p. 355 f. even claiming that the motif was something unique to Waltharius). The only exception known to the author is Ratkowitsch, 2016, p. 17 f., who traces the motif back to the Iliad (via the Ilias Latina), but fails to give a proof for her claim and anyway seems unaware that the motif of wrath and withdrawal can be found in other medieval traditions, too.

${ }^{31}$ Similarly in line 28 Hagano is said to be of Trojan stock.

${ }^{32}$ Verg. Aen. 1,458 and 1,483-487.

${ }^{33}$ Ov. Am. 1,9,33; Am. 2,8,11; Am. 2,18,1; Am. 3,9,1 f.; Her. 8,85 f.; Her. 20,69; Ars 1,441; Ars 2,403 f.; Ars 2,711-716; Rem. 465-484; Rem. 777-784; Trist. 2,373 f.; Trist. 4,1,15 f.; Trist. 5,1,55 (the most extensive treatment of the Trojan War by Ovid is the lenghty passage in Met.12,580-628 and 13,1398, but this passage focuses on events following the conflict between Achilles and Agamemnon). 
Phrygian. But in these novels the motifs are considerably transformed, especially in Dares which is the medieval classic for the legend of Troy. ${ }^{34}$ For example in Dictys' Ephemeris the story indeed unfolds rather as in the Iliad with Briseis being taken away from Achilles, and there is an embassy of Agamemnon with three ambassadors as in book 9 of the Greek epic. ${ }^{35}$ But Achilles reenters battle not because of a reconciliation with Agamemnon but because of his love for Polyxena and his infamous treatment by Polyxena's brother Hector. ${ }^{36}$ In addition to that, Patroclus is killed only after Achilles had resumed fighting again. ${ }^{37}$ Similarly, in Dares' Acta diurna Achilles abstains from battle just because of his love for Polyxena and never gets insulted by Agamemnon in the way he gets in the Iliad. ${ }^{38}$ There are again fruitless or only partially successful embassies, ${ }^{39}$ but the decision to reenter battle is only taken when the Trojan prince Troilus seriously endangers the Greek troops. ${ }^{40}$ There remains Hyginus whose Fabulae (chapter 106) fairly closely follows the traditional story. But the Fabulae was not a widespread text in the Middle Ages, and there is no hint at the various pleas for reconciliation, something that is quite prominent in Waltharius.

The best candidate for being the model of Waltharius is therefore the Ilias Latina, and it seems that there was indeed a copy of it available at St. Gall at the respective time. ${ }^{41}$ This poem essentially is a condensation of the whole Iliad to a text of 1070 lines, having its origin in the Neronian period. So we here get a correct picture of the action. But the poet is strangely disinterested in the back-bone of the story. For example, there is no formal declaration of withdrawal by the angered hero, ${ }^{42}$ something we have in Waltharius. ${ }^{43}$ The whole embassy of book 9 is treated within bare ten lines, ${ }^{44}$ and there is no scene of formal

\footnotetext{
${ }^{34}$ See for example the remarks by Wolf, 2009, p. 131-136. It is telling therefore that the most ambitious medieval treatments of the story of the Trojan War, the Roman de Troie by Benoit de Sainte-Maure (ca. 1165 AD, in Old French) and the Ylias by Joseph of Exeter (ca. 1180 AD, in Latin), followed Dares with his distorted representation of Achilles' wrath, and not something closer to Homer's original as the Ilias Latina.

${ }^{35}$ Dictys, bk. 2,33-37 and 2,48-52.

${ }^{36}$ Dictys, bk. 3,5.

${ }^{37}$ Dictys, bk. 3,10-11.

${ }^{38}$ Dares, ch. 27-28.

${ }^{39}$ Dares, ch. 30-32.

${ }^{40}$ Dares, ch. 33.

${ }^{41}$ Scaffai, 1997, p. 29 f. (with n. 48). However, the claim by Bisanti, 2002, p. 186 f., that the poet of Waltharius actually used the Ilias Latina, could not be verified by the present writer.

${ }^{42}$ Contrarily to the Iliad (1,233-244) the withdrawal in the Ilias Latina is only implied in Thetis' advice to her son not to fight again for Agamemnon (v. 80-86), but never formally declared.

${ }^{43}$ Waltharius, v. 632-639.

${ }^{44}$ Ilias Latina, v. 686-695, without the three ambassadors and their respective speeches being mentioned separately (book 10 on the other hand, which is much less favoured by modern Homerists, is treated in more than forty lines [v. 696-740]).
} 
reconciliation between Achilles and Agamemnon, something we should absolutely postulate as a model for the analogous scene between Hagano and Guntharius. ${ }^{45}$

Anyway it must be said that despite its basic identity with the plot of the Iliad the motif of wrath and withdrawal in the Song of Waltharius shows considerable differences as well, which speak against the assumption that the medieval Latin poem might be derived from the Iliad or its ancient Latin derivatives. For example, there is a very straightforward offence Guntharius utters against Hagano, blaming him not only for personal cowardice but even for cowardice - borribile dictu - inherited from his ancestors. ${ }^{46}$ In the Iliad there is the same motif of offence, but it is treated in a much more convoluted way. Here the offence is rather implicit consisting mainly of the act of taking away Briseis from Achilles, and so far as words are concerned, Agamemnon just stresses that Achilles is most hated by him and that he himself is socially superior ${ }^{47}$ This time, it is rather the hero who blames his king for cowardice. ${ }^{48}$ Another important difference consists in the motif of the embassy: When things are really starting to take a bad turn, Guntharius himself goes to the sulking Hagano and in a series of three speeches asks for forgiving, ${ }^{49}$ the first plea being answered negatively, the second one not answered at all, and the third one finally answered positively. In the Iliad, on the contrary, the king himself stays behind and rather sends out three ambassadors (Odysseus, Phoenix, Ajax), who however with their respective speeches do not manage to change Achilles' mind. The Song of Waltharius therefore in this respect does not so much remind us of the Iliad but rather of several other medieval or post-medieval European epic poems, which have a similar row of pleas, the third one always being successful..$^{50}$ The third

\footnotetext{
${ }^{45}$ The various events of book 18 of the Iliad like Achilles' mourning over the body of Patroclus or the description of his new weapons, in the Ilias Latina are immediately followed by Achilles' fight with Aeneas (v. 839-891 and 892-902 respectively). The reconciliation with Agamemnon in book 19 of the Iliad is therefore completely left away.

${ }^{46}$ Waltharius, v. 629-631.

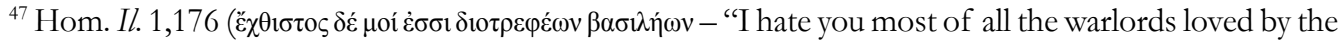

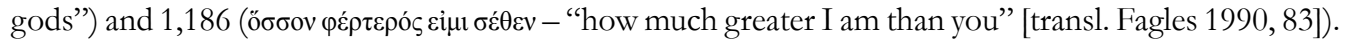
${ }^{48}$ Hom. Il. 1,225-232.

${ }^{49}$ Waltharius, v. 1065 (precibus), 1073 (precibus nibilominus instans), and 1092 (supplicius tamen infelix rex institit illi).

${ }^{50}$ So in the Irish Táin bó Cúalnge (ch. X), where Queen Medb sends out three successive ambassadors to the enemy hero Cuchulainn in order to ask for a truce (O’Rahilly, 1967, p. 176-183), in the Spanish Poema de mio Cid (v. 870-898, 1316-1384 and 1831-1915), where the banished hero Cid three times sends his nephew Albar Fáñez to King Alfonso in order to ask for the permission to return to Castilia (Smith, 1972, p. 28 f., p. 43-45, and 58-61), and in the Serbian song of Marko Kraljevic and Mina of Kostur (v. 126-159), where the Turkish sultan sends three letters to the Serbian hero Marko in order to call him back to battle (cf. the translation of the relevant part by Grossardt, 2009, p. 142 f.). This sequence of two failing embassies (or speeches or letters) and a final successful one certainly was traditional, as can be gleaned from the same sequence in the Homeric Hymn to Demeter (v. 314-324, 325-333 and 441-471) and in the Roman story of Coriolanus (Liv. 2, 39-40; cf. the comments by Grossardt, 2009, p. 28-30). In addition to that, one may point to the three successive talks between Count Guillaume and King Louis in the beginning of the Old French Charroi de Nîmes; cf. the discussion below in chapter 2.2.
} 
major difference lies in the motif of the death of the substitute. In the Song of Waltharius the death of Hagano's nephew Patavrid, who fights as sixth in the row, certainly marks a point of culmination in the story and is heavily mourned by Hagano. ${ }^{51}$ But it doesn't lead to Hagano reentering battle right again. This happens only when five more warriors have been killed by Waltharius and Guntharius himself is expected now to enter battle against the Aquitainian hero. Hagano even denies that his decision to change his mind is caused by Patavrid's death and claims that he acts out of loyalty for Guntharius, ${ }^{52}$ whereas in the Iliad Achilles reenters battle for no other reason but to take revenge for Patroclus.

It might, of course, be argued that the motif of a beloved's death had indeed been taken from the Iliad and that by denying its importance the poet of Waltharius secretly shows that he knows this sequence of events, but consciously changed it. But the death of the substitute is again a very common motif with significant parallels in traditional European epics. For example, in the aforementioned Irish epic Táin bó Cúalnge the leading hero Cuchulainn due to exhaustion falls asleep for three days and nights. During this time his cousin Follomain fights in his stead, but soon gets killed. ${ }^{53}$ Or in the traditional Yugoslav song Seven kings seek the head of Đerdelez. Alija the hero Alija hides from his persecutors, but soon has to learn that his nephew Beg Ljubović, who exactly looks like him, has been captured and beheaded in his stead. What is more, as with Hagano and Patavrid, this is a case of an uncle and his sister's (and not his brother's) son. ${ }^{54}$ So the conclusion should be that the poet of Waltharius didn't depend on the Iliad or the Ilias Latina, but rather worked within an indigenous medieval European tradition. The deviation from the traditional pattern, which demanded the hero's reentering battle right after the substitute's death, should therefore be a deviation from an inherited pattern, perhaps still found in an older version of the story of Waltharius, ${ }^{55}$ but certainly not a conscious deviation from the Iliad. The overall conclusion, accordingly, is that it can't be ruled out with absolute certainty that the motif of wrath and withdrawal in Waltharius was derived from the Iliad, but that this scenario is highly improbable. Instead, the motif of wrath and withdrawal by all probability belonged to a stock of traditional heroic subjects, circulating in early Europe, and it was adopted from there into an early (lost or purely oral) version of the tale of Waltharius and Hiltgunt, from where it reached not only the Latin Song of Waltharius, but also the Old English poem of Waldere and the Song of the Nibelungen. The Song of Waltharius is thus independent from any ancient Greek or Latin model and may serve as yet another self-standing testimony for the

\footnotetext{
${ }^{51}$ Waltharius, v. 846-877.

${ }^{52}$ Waltharius, v. 1112-1114 (nam propter carum (fateor tibi, domne), nepotem / / promissam fidei normam corrumpere nollem. // ecce in non dubium pro te, rex, ibo periclum).

${ }^{53}$ Táin bó Cúalnge, ch. XVII 1-2 (O’Rahilly, 1967, p. 197-199). The episode is followed by an immediate act of revenge by Cuchulainn that strongly reminds of Achilles' actions after the death of Patroclus; cf. the comments by Grossardt, 2009, p. 47 and p. 111.

${ }^{54} \mathrm{Cf}$. the summary of the epic and the discussion of its analogy with the Iliad by Lord, 1969, p. 28-30.

${ }^{55}$ Such a version might be reflected in v. 1264-1279, where Hagano contrary to his prior claim (v. 1112-1114) now states that it is indeed for the sake of avenging his nephew that he engages in combat with Waltharius.
} 
central epic motif of wrath and withdrawal. ${ }^{56}$ As we shall presently see, this conclusion is confirmed by a study of the medieval French tradition of the chansons de geste.

\section{The Old FRENCH SONGS ABOUT GUILLAUME AU NEZ COURBE}

Guillaume au nez courbe ('Guillemes al curb nes' - 'William the hook-nosed') or Guillaume au nez court ('al curt nes' - 'the snub-nosed'), according to legend, was a brave warrior, whose robust personality is somewhat reminiscent of mythic heroes like the Greek hero Diomedes or the Indian hero Bhima, one of the most valiant warriors of the Indian national epic Mahabharata. ${ }^{57}$ He was, however, a historical person, known as Guillaume de Toulouse (alternatively as Guillaume de Gellone or Guillaume d'Orange), a cousin of Charlemagne, who in the year 790 was made governor of south-western France and therewith counsellor of the king's under-age son Louis. He fought some successful battles against the Saracens, even helping to capture Barcelona for the Frankish kingdom, but in the year 804 he retired to a monastery and in 806 he founded another monastery, where he died in $812 .{ }^{58}$ These exploits, already at the time, had some resonance, and so Guillaume first appears in the year 827 in the panegyric Carmina in honorem Hludowici Pii by Ermoldus Nigellus as one of the knights to have conquered Barcelona together with Louis. ${ }^{59}$ Soon, however, he was transformed into a hero of more fanciful legends, who (allegedly) not only took part in Charlemagne's famous campaign to Saragossa, ${ }^{60}$ but was also credited with the purely fantastic conquests of Nîmes and Orange. ${ }^{61}$ These epic traditions - in purely oral or early written form - must have been established at the latest by the year 1100, as several sources of the early twelfth century attest to such songs. ${ }^{62}$ The preserved epic poems about

\footnotetext{
${ }^{56}$ For the other testimonies like the Iranian, Indian and Serbian examples being independent of the Iliad see the discussion by Grossardt, 2009, p. 48-53.

${ }^{57}$ For the type of hero represented by Guillaume and for its possible Indo-European roots cf. Fassò, 1997 and Grisward, 1997, p. 452 f.

${ }^{58}$ For Guillaume's biography and for his transformation into an epic hero see the detailed treatment by Frappier, 1955, p. 64-87 and the synopsis by Lachet, 1999, p. 8-12.

${ }^{59}$ Ermoldus Nigellus, Carmina in honorem Hludovici Pii, v. 102-571 (Faral, 1932, p. 12-46).

${ }^{60}$ As attested in the Nota Emilianense (ca. 1065-1075 AD); cf. the edition of the text in Alonso 1961, p. 96. ${ }^{61}$ Vita sancti Willelmi, ch. 6 (Mabillon, 1735, p. 71 [dated to ca. 1125]: itaque Septimaniam ingressus, transito quoque Rhodano ad urbem concitus Arausicam [sc. Orange] agmina disponit et castra: quam illi Hispani [sc. the Saracens] cum suo Theobaldo iampridem occupaverant, ipsam facile ac brevi caesis atque fugatis eripit invasoribus, licet postea et in ea et pro ea multos et longos ab hostibus labores pertulerit, semperque praevaluerit decertando); Liber sancti Jacobi (= Codex Calixtinus), bk. 5,8 (Vielliard, 1938, p. 48 [dated to ca. 1139-1145]: hic [sc. Guillaume] urbem Nemausensem [sc. Nîmes] ut fertur et Aurasicam aliasque multas xpistiano imperio sua virtute potenti subjugavit). For the non-historicity of Guillaume's most celebrated military successes in the Provence see however Lachet, 1999, p. 29 and Lachet, 2010, p. 47; for a possible origin of the tradition about Nîmes see Hoggan, 1977, p. 35 f.

${ }^{62}$ Letter by Pope Paschal II to Bishop Béranger of Orange in 1112 (quoted after the excerpt in ColbyHall, 1980/1981, p. 339 f.: [Aura] sice siquidem civitatis populus aliquando ita exaltatus est, ut illius civitatis nomen
} 
Guillaume date from the middle of the twelfth century or later and were then combined to epic cycles, the core cycle consisting of the triptych Couronnement de Louis, Charroi de Nîmes and Prise d'Orange, which treats the most famous achievements of Guillaume at the height of his career. ${ }^{63}$

\subsection{Guillaume AND RAINOUART IN THE CHANSON DE GUILLAUME}

The Chanson de Guillaume stands somewhat apart from the main cycle of the songs about the exploits of Guillaume and actually treats an event of his more mature years. ${ }^{64} \mathrm{It}$ is nevertheless roughly contemporary with the songs of the Cycle and here shall be dealt with first, because it offers a good parallel to an incident which in Achilles' life comes first, too. The song is anonymous and dates from the middle of the twelfth century. ${ }^{65}$ It consists, however, of two rather uneven parts which indicate that the remanieur of the whole song combined two originally independent songs ${ }^{66}$ There is nevertheless an overarching thematic unity with the Saracens attacking the French town Larchamp, ${ }^{67}$ killing Guillaume's brave nephew Vivien and taking captive his other nephew Bertrand. Only after many incidents Guillaume and his troops finally manage to defeat the invaders.

After Vivien's death things look desperate for the Franks. Guillaume therefore goes to King Louis in order to ask for help. The king declares not being able to give any help, but the young lad Rainouart (Old French 'Reneward' or 'Rainoarz', also transliterated as 'Renouart'), up to then working under very humble conditions in the king's kitchen, approaches Guillaume and offers his succour. ${ }^{68}$ His special weapon is his tinel, essentially a large beam carried on the shoulders in order to fetch water in two buckets hanging down from the beam, but used by

vulgaribus passim carminibus celebretur); Vita sancti Willelmi, ch. 2 (Mabillon, 1735, p. 69: quae enim regna et quae provinciae, quae gentes, quae urbes, Willelmi Ducis potentiam non loquuntur, virtutem animi, corporis vires, gloriosos belli studio et frequentia triumphos?) and ch. 6 (p. 71: unde et civitas illa [sc. Orange] ad tanti Ducis gloriam famosissima multumque celebris, magnique nominis per totum hodieque mundum commemoratur); Ordericus Vitalis, Hist. eccl. 6,3 (Chibnall, 1972, p. 218 [dated to ca. 1130-1137]: vulgo canitur a ioculatoribus de illo [sc. Guillaume] cantilena). ${ }^{63}$ For the formation of the epic cycle or cycles around the person of Guillaume cf. Suard, 2011, p. 117-120 and 131-137; for a general treatment of the complex interplay between orality and literacy in the French chansons de geste cf. Poirion, 1972 and Boutet, 2012.

${ }^{64}$ The Chanson de Guillaume will henceforth be quoted after the Modern French translation by Suard, 2008. A critical editio maior of the Old French original may be found in Wathelet-Willem, 1975, v. 2, p. $729-1073$.

${ }^{65}$ Suard, 2008, p. 26 f.

${ }^{66}$ Suard, 2008, p. 16-21, with a survey of the preceding scholarly debate on the question.

${ }^{67}$ A fantasy town, located at the coast of the sea, perhaps to be identified with modern Arles (Suard, 2008, p. 25).

${ }^{68}$ For the person of Rainouart see the different perspectives taken in the papers by Adler, 1951/1952; Lejeune, 1970; Wathelet-Willem, 1977 and 1984; Williamson, 1985 and Grisward, 1997. 
Rainouart as a gigantic club. ${ }^{69}$ Despite a somewhat naive personality, a gluttonous appetite and other ridiculous features, Rainouart succeeds in beating the Saracens and secures the final victory for Guillaume.

At the end of the poem it turns out that Rainouart was the son of the Saracen king Deramé of Spain, who as a child had been taken hostage and sold to France. He is therefore the brother of Guillaume's wife Guibourc, and at the end of the story gets baptized. His process of initiation is thus accomplished. But before this can happen, the Franks at Orange want to celebrate their victory, but unfortunately forget to invite Rainouart and therewith severely offend their main hero. ${ }^{70}$ Predictably, Rainouart reacts with anger and decides to switch sides, that is to return to his native country and to attack the Franks from there. ${ }^{71}$ Guillaume soon understands that he has made a serious mistake and sends out an embassy in order to make amends. But the ambassadors get turned down and many of them are even killed. ${ }^{72}$ It takes a second embassy by Guillaume himself and his wife in order to convince Rainouart that he give in and accept the apology. ${ }^{73}$

We thus get all the main elements of the pattern of wrath and withdrawal with the hero's offence by his superior, with his angered reaction, with a first fruitless attempt at making amends and with the final reconciliation, that is, with all the traditional elements known from the Iliad and the other epic poems mentioned above. The best Greek parallel for the story of Rainouart and Guillaume, however, is not represented by the Iliad but by an incident somewhat earlier in Achilles' career as a hero, when Agamemnon with his troops, before entering Trojan soil, makes a rest on the island of Tenedos. Unfortunately Agamemnon, too, forgets to invite his main hero to the feast in his tent, and Achilles predictably reacts with anger. This was told in the Cypria, the epic treating all the events of the Trojan War up to year ten of the hostilities, that is up to the beginning of the Iliad. Today the Cypria is lost, but fortunately we still have a summary by the late antique grammarian Proclus, who briefly

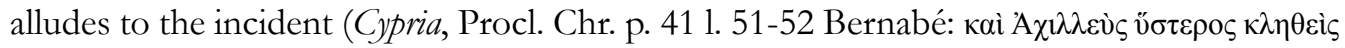

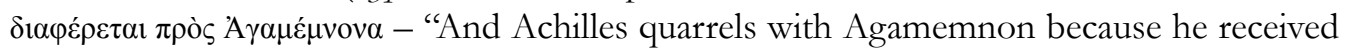
a late invitation." 74 ). As Guillaume, Agamemnon soon must have understood that he made

\footnotetext{
${ }^{69}$ Rainouart is thus the 'last descendant' in an illustrious row of gods or heroes, all fighting with a heavy club, like the Sumerian god Ninurta (or Ningirsu), the Babylonian god Eragal (or Nergal) and the Greek hero Hercules; cf. Burkert, 1979, p. 80-83.

${ }^{70}$ v. 3351 («Ce fut folie lorsque Renouart y fut oublié.»).

${ }^{71}$ v. $3355-3372$.

${ }^{72}$ v. 3381-3448. See especially Guillaume’s offer for reconciliation in v. 3416-3418 («Guillaume vous demande de venir; il veut vous dédommager pour le tort qu'il vous a fait, pour le repas où vous avez été oublié.»).

${ }^{73}$ v. 3450-3477. See especially Rainouart's speech of acceptance (v. 3466 f.: «Je vous pardonne aujourd'hui la noire trahison que vous avez faite en m'oubliant pour le repas.») and the poet's description of the final reconciliation (v. 3474-3477: «Guillaume et Renouart sont désormais réunis; ils ont fait la paix de grand cœur et se dirigent vers la cité d'Orange: vous pouvez imaginer que le repas fut prêt sur-le-champ.»).

${ }^{74}$ Translation by West, 2003, p. 77.
} 
a serious mistake ${ }^{75}$ therefore asks for forgiving and either at once or after a certain delay succeeds in reconciling Achilles.

The parallel between Achilles and Rainouart is all the more striking, as in both cases the angry reaction is not so much triggered by a missed meal but by the hurt feelings of a leading hero who has been overlooked and takes this as a slight at his honour. ${ }^{76}$ Nevertheless it is hardly conceivable that the French song depends on the incident told in the Cypria. Proclus' summary of the Cypria is preserved in some ten manuscripts, but these are all manuscripts of the Iliad, all of which were still in the realm of Byzantium at the time and hadn't reached the Occident as yet. It is quite the same with the few other witnesses for the story: The Syndeipnoi by Sophocles (TrGF 4 F 562-571) must have treated the story on a rather large scale. But the play is attested in but a few fragments and in addition to that, it seems to have blended the conflict between Achilles and Agamemnon with another quarrel between Achilles and Odysseus. ${ }^{77}$ The brief mention of the story in Aristotle's Rhetoric (2,24,6, 1401b16-20) is about as hidden and allusive as the short remark by Proclus, and though Aristotle was not completely unknown in the Latin West, his works were certainly beyond the horizon of a trowvere or jongleur of chansons de geste. There is indeed one Latin testimony of the story, that is Dictys of Crete's Ephemeris belli Troiani. But this testimony is again rather short and again mixes up the story with another story, this time with the story of Achilles being angry because of the abduction of Briseis (Dict. 2,36: Is [sc. Achilles] namque, quamquam ob inlatam ab Agamemnone iniuriam et abductam Hippodamiam [= Briseis] nibil animi remiserat, tamen maxime indignatus, quod reliquis ducibus ad cenam deductis solus contemptui habitus intermitteretur.). Certainly no singer in the Middle Ages would have undertaken the almost scholarly task to undo this process and to separate again one story from the other.

We can therefore safely conclude that the parallel between Achilles and Rainouart is not the result of a cultural transfer from the learned world of the East to the practitioners of the art of story-telling in the West that took place in the High Middle Ages. Another option might seem more probable, that is, a reintegration of a literary motif into the oral world of story-telling that took place in late Antiquity and a subsequent process of migration of this very story through the Arabic world of northern Africa and Saracen Spain, until it reached southern France sometime around the end of the first millenium. But again, the story had already been so little known in Roman times that it would not have reached an oral stratum of story-telling from the start. We are therefore left with the third possibility, that is, that we are dealing with an old traditional motif of oral epic story-telling that reached the worlds

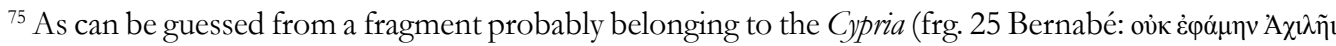

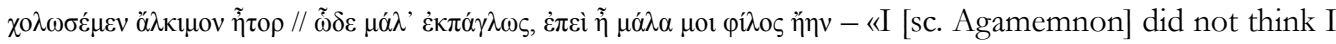
would anger Achilles' brave heart so very greatly, as he was my good friend.” [transl. West, 2003, p. 101]). ${ }^{76}$ This holds true even for the ever hungry Rainouart, as has been correctly seen by Wathelet-Willem, 1984, p. 291 («Après la victoire, quand Guillaume commet la bévue d'omettre d'inviter Rainouart au banquet qui réunit les chefs de l'armée, la colère du jeune homme n'est nullement provoquée par la gourmandise frustrée, mais par l'amour-propre froissé.»).

${ }^{77}$ See the remarks in Grossardt, 2009, p. 60 f. (with further literature).
} 
of Greek and French epic independently of each other. ${ }^{78}$ This conclusion, which could be strengthened by a look at other heroic or folkloristic traditions, ${ }^{79}$ corresponds to the one reached above with respect to the Song of Waltharius, but will be confirmed by still more analogous cases in the world of the French chansons de geste.

\subsection{GuILlaUme AND KING LOUIS IN THE CHARROI DE NîMES}

The Charroi de Nimes forms the middle part of the cycle of the three central songs about Guillaume with the Couronnement de Louis as the first part and the Prise d'Orange as the last one. ${ }^{80}$ All three songs presuppose the whole story of the cycle and refer to each other with flash-backs and passages of foreshadowing. They thus point to an earlier tradition, but probably were not composed by the same singer, the Charroi de Nimes dating from about the middle or the end of the twelfth century. ${ }^{81}$

Thus, despite being part of a larger cycle, the Charroi de Nimes doesn't immediately follow the action of the preceding epic, which told about Guillaume's help for his brotherin-law King Louis, who otherwise would not have been able to become king and to keep his power. Instead, after an undetermined time-gap, the Charroi de Nimes rather suddenly opens with a conflict between Guillaume and Louis taking place in Paris ${ }^{82}$ Louis, when

\footnotetext{
${ }^{78}$ Such analogies between the ancient Greek and the medieval French tradition might be due to the common Indo-European background, as has often been postulated in French medieval studies from the nineteensixties onwards (see the programmatic article by Grisward, 1982 and the critical evaluation of this school by Boutet, 2005). But as we shall see in the conclusion of this paper, there are Near Eastern parallels for our motifs, too, so that it is safer to base our argument on the assumption of migrating tales, whether Indo-European or not (see the methodological discussions of Hansen, 2002, p. 1-31 and Grossardt, 2009, p. 1-14).

${ }^{79}$ See especially the Russian heroic poem of Ilja Muromec and his superior, Prince Vladimir of Kiev, who forgot to invite his foremost champion to the feast in his palace, therefore had to face Ilja's anger and raging, and only through an embassy of another of his main heroes reached a state of reconciliation (English translation in Chadwick, 1932, p. 61-65; summaries and short discussions of the song in Trautmann, 1935, p. 385-387 and Oinas, 1978, p. 243). On the divine level, in Greece again, there is the goddess Eris ('Strife'), who was overlooked at the wedding of Peleus and Thetis, Achilles' future parents, and therefore triggered the Trojan War (Cypria, with the summary by Procl. Chr. p. 38 1. 4 - p. 39 1. 8 Bernabé; Apollod. Epit. 3,2; POxy. 3829 II 9-22 [republished and translated in West, 2003, p. 80 f.]; Luc. DMar. 7,1 and Symp. 35; Hyg. fab. 92,1). See the general classification of the motif in Thompson, 1955-1958, v. 3, p. 71 (F 361.1.1) and Uther, 2004, v. 1, p. 244 f. (type 410), who point to the beginning of the Brothers Grimm's fairy-tale Sleeping Beauty (Dornröschen), where a fairy, unlike twelve other fairies, is not invited to the celebration of a baptism and therefore curses the newly born child.

${ }^{80}$ The Charroi de Nimes will henceforth be quoted from the Modern French translation by Lachet, 1999. A critical edition may be found in McMillan, 1972.

${ }^{81}$ A date in the middle of the twelfth century has been proposed by Frappier, 1967, p. 186 and McMillan, 1972, p. 41-43, a date at the end of the century by Hoggan, 1977, p. 35.

${ }^{82}$ For the ideological background of the poem as expressed through this conflict between Guillaume and Louis cf. the different positions of Bender, 1967, p. 67-70; Hunt, 1978 and Heintze, 1991, p. 205;
} 
distributing fiefs to the people of the nobility, had forgotten to award a fief to Guillaume. Guillaume, not willing to put up with such ingratitude, enters the royal palace and confronts Louis with his misdemeanour. The king soon realizes that what he did was indeed wrong and offers compensation like a fief already given to someone else or even a fourth of his own kingdom. But Guillaume, who is very sensitive to public opinion and does not want to profit from someone else's loss, refuses to accept this offer. Instead, he threatens to switch sides and to fight for the Saracens from now on ${ }^{83}$ and at some point he even threatens that he might use violence in a personal duel between him and the king. ${ }^{84}$ Confronted with such a reaction, all Louis can do is to state that this is indeed a case of severe anger. ${ }^{85}$ We thus have another nice parallel to the various disputes between Achilles and Agamemnon in the Greek tradition. ${ }^{86}$

After his first encounter with Louis (v. 51-414) Guillaume leaves the palace in frustration. But on his way out he meets his nephew Bertrand, who had been waiting for him. Bertrand, when told about the negative outcome of the negotiations, comes up with a new idea. Guillaume should propose to the king that he would conquer Spain (including southern France with the beautiful towns of Nìmes and Orange) from the Saracens and take this region as his fief. This meets well with Guillaume's sense of honour, and therefore in a second talk (v. 463-677) Louis and Guillaume agree to follow this plan. Finally, having left the court, Guillaume is notified by a messenger that the traitor Aymon slandered him with the king, returns to the palace for a third time, kills Aymon in front of the king and leaves the palace with the good wishes of his chief (v. 696-764).

There are therefore parallels to as well as divergences from the familiar pattern of wrath and withdrawal. We have the same motifs of offence, anger, withdrawal, offer of compensation, failed reconciliation and finally rearrangement of matters. But the situation is less dramatic than in the other cases, because it is not a situation of acute war-time and therefore the offended hero can only threaten to join the enemy, but cannot actually boycott an ongoing war, and it is even the hero himself who, after a first moment of anger and frustration, opens the way for reconciliation. Nevertheless the poet of the epic seems to have been familiar with the more classical pattern, as is shown by his rather artificial use of the traditional sequence of three encounters or exchanges of speeches between the king (or

for the larger context of the so-called 'epic of revolt' see Calin, 1962; Adler, 1963 and Grisward, 1993. ${ }^{83}$ Charroi de Nimes, v. 94-101, 112-114 and 269-271 («... mais par Celui qui demeure là-haut dans le ciel, je me retournerai contre mon suzerain. Tu pourras faire en sorte que je ne sois plus ton familier.»). ${ }^{84}$ v. 291.

${ }^{85}$ v. 295 and 301 («à présent je le vois bien, vous êtes très en colère»). The same term for the wrath of the hero (sc. 'colère' or 'rancœur', Old French 'maltalant') had been used already in a comment by the epic singer (v. 104 f.: "Dès lors leur désaccord commence à s'envenimer et leur colère réciproque s'accroît.”) and in a statement by Guillaume himself (v. 119: "La rancœur me contraint à quitter la cour."), and it later will mark the end of the episode (v. 414: "plein de rancœur, il [sc. Guillaume] descend l'escalier"). ${ }^{86}$ Even though Guillaume now takes the role of Achilles and not any more - as in the Chanson de Guillaume - the role of Agamemnon. 
his ambassadors) and his hero. ${ }^{87}$ But what is at least as important as this sequence of three encounters, is the placement of the episode right at the beginning of an epic telling of the conquest of a town with the help of a ruse.

Guillaume, when having left Paris in order to conquer southern France, decides first to attack Nîmes which is currently held by the Saracens. But as the town is well fortified, Guillaume follows the advice of one of his counsellors to hide one thousand soldiers in big barrels, to place the barrels on carriages (hence the title of the song), to disguise himself as a merchant having come to sell his goods, and so to enter the town. The ruse succeeds and conquering the city is now an easy matter. This is indeed an old motif of folklore, which in a similar form is attested already in the Old Egyptian tale of the conquest of the Palestinian city of Joppa (Jaffa), ${ }^{88}$ but has many parallels in the medieval Arabic tradition and perhaps from there reached Spain and France. ${ }^{89}$ But there is, of course, another classical parallel with the story of the Trojan Horse, and we should remember that the Iliad, though not actually telling the fall of Troy, alludes to the coming ruse, ${ }^{90}$ and certainly opens with the conflict between Agamemnon and Achilles. So, to begin an epic, that tells the conquest of a well fortified town, with an argument between king and hero, was obviously an idea as natural to an ancient Greek poet as to a medieval French jongleur. ${ }^{91}$

\section{THE QUARREL BETWEEN CHARLEMAGNE AND ROLAND IN THE GESTE DE FIERABRAS}

The beginning of the Charroi de Nimes we just discussed is, however, not the only parallel to the Iliad within the world of the Old French chansons de geste. There is an even closer parallel, indeed a striking one, in the Geste de Fierabras. ${ }^{92}$ This is the second part of a diptych which in its first part tells the destruction of Rome by the Saracens, the killing of the pope and the stealing of some most valuable relics like the shroud of Jesus. Having accomplished this feat the Saracens, led by their emir Balan (or 'Laban') and his son Fierabras, a gigantic hero, retire to Spain, and Charlemagne who had been called to help but arrived too late in

\footnotetext{
${ }^{87}$ See above the sequence of the three speeches by King Guntharius addressed at the angry Hagano and the other examples from comparable epic traditions (above n. 50).

88 The story is attested on a papyrus of ca. 1300 BC (English translation in Pritchard, 1969, p. 22 f.). It has been aptly compared with the legend of the Trojan Horse by Hölscher, 1989, p. 61 f. and Hansen, 2002, p. $171 \mathrm{f}$.

${ }^{89}$ Cf. Galmés de Fuentes, 1972, p. 129-131.

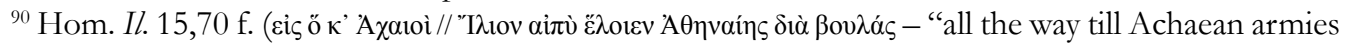
seize the beetling heights of Troy through Athena's grand design” [transl. Fagles, 1990, p. 389 f.]).

${ }^{91}$ It is telling that the last line of the Couronnement de Louis points to this sudden opening of the following poem (v. 2695: "Quand il [sc. King Louis] fut puissant, il n'en sut point gré à Guillaume" [Lanly, 1983, p. 118; Old French original in Langlois, 1925, p. 84]), even though this may be an addition of a remanieur, and not part of the original song (Frappier, 1967, p. 181).

92 The parallel has been mentioned and briefly discussed by V. Zhirmunsky (1961, p. 63; 1962, p. 133 f.), M. Ailes (2002, p. 11) and M. Le Person (2003, p. 185; 2012, p. 29).
} 
Rome follows them with his troops oversea. ${ }^{93}$ There, in a single combat, Fierabras inspite of his strength is defeated by Charlemagne's vassal Olivier, and after many an incident the Franks manage to beat Balan's troops, to conquer the town of Aigremore, to regain the relics and to capture Balan's beautiful daughter Floripas who anyway had fallen in love with the French knight Gui de Bourgogne and will now marry him. ${ }^{94}$ Charlemagne returns to Paris and makes a deposit of the relics at the cathedral of Saint-Denis, but in an epilogue the poet tells us that three years later the devastating defeat of Roncevaux (778 AD) with the tragic death of Charlemagne's nephew Roland will happen. ${ }^{95}$

We can thus observe in Fierabras a general parallel with the legend of the Trojan War, with an army following an enemy to his home-place overseas, with the conquest of a city and with the capture of a beautiful woman. But what makes Fierabras important within the context of our topic, is not this general resemblance but the precise opening of the poem. Having arrived in Spain, the Franks engage in a first battle with the Saracens, but suffer a serious defeat, where Olivier is severely wounded and his friend Roland just manages to save their lives. But in the evening Charlemagne who with a troop of elderly warriors had come to help blames his nephew for this defeat. Roland takes this as a serious offence, and in the next morning, when Fierabras challenges the Franks for a single combat, Roland refuses to fight and even threatens to kill his uncle. Thus, Olivier inspite of his wounds engages in the duel with Fierabras and actually beats him. But in the ensuing battles he is captured by the Saracens, and this finally makes Roland change his mind, so that he takes part in the fighting again.

So, there is a long list of parallels with the Iliad. A brave hero is offended by his chief, reacts with anger and decides to withdraw from battle. ${ }^{96}$ His retinue is told to act like the hero himself. ${ }^{97}$ When the argument continues, the hero draws his sword against his king. ${ }^{98}$ People close to the hero prevent him from killing his king. ${ }^{99}$ When the king orders

\footnotetext{
${ }^{93}$ For summaries of Fierabras, the second part of the diptych, see Reichl, 1984; Suard, 2011, p. 193196 and Le Person, 2012, p. 149-173.

${ }^{94}$ For the person of Floripas in Fierabras and in the later tradition see Keller, 1993.

${ }^{95}$ The Geste de Fierabras will be quoted after the line-numbers in the critical edition of Le Person, 2003 (the allusion to the defeat at Roncevaux being in lines 6396-6404) and after the page-numbers in the Modern French translation by Le Person, 2012 (Roncevaux: p. 574 f.).

${ }^{96}$ Fierabras, v. 39 (Le Person, 2012, p. 267) and v. 147-167 (Le Person, 2012, p. 274 f.: «Sire, dit Roland, ne m'en parlez jamais plus, car, par ce Seigneur que l'on appelle Dieu, je préférerais que vous ayez les pieds coupés plutôt que de prendre les armes et de m'équiper pour cela.»); Hom. Il. 1,130-187 and 1,223-246.

${ }^{97}$ Fierabras, v. 165-167 (Le Person, 2012, p. 275); Hom. Il. 1,306 f., 2,686 f. and 16,203 f.

${ }^{98}$ Fierabras, v. 172 (Le Person, 2012, p. 275: «Roland mit la main à son épée et l'a retirée du fourreau»); Hom. Il. 1,188-192.

${ }^{99}$ Fierabras, v. 173 (Le Person, 2012, p. 275 f.: «il en aurait aussitôt frappé son oncle, si l'on ne l'en avait empêché»); Hom. Il. 1,193-222 (Athena stops Achilles from using violence).
} 
his people to act against the hero, the soldiers hesitate to obey. ${ }^{100}$ Nevertheless the hero threatens to act violently against the king or his servants. ${ }^{101} \mathrm{~A}$ wise elderly person tries to mediate between the king and the hero laying some blame on both of them. ${ }^{102}$ The king now understands that this wrath can't be healed so easily, but nevertheless he is not ready to apologize and continues to act against the hero. ${ }^{103}$ The sulking hero soon longs to fight again. ${ }^{104}$ Therefore he observes the others fighting. ${ }^{105}$ Finally, he reenters battle in order to free his captured friend or to save his dead friend's body. ${ }^{106} \mathrm{He}$ swears not to relent, until his friend is freed again or avengend. ${ }^{107}$

There is thus an almost perfect parallel between Fierabras and the Iliad, the only major differences being that the person who fights in the hero's stead in the one case (Olivier) is only captured by the enemy, whereas in the other case (Patroclus) he gets killed, and that Roland soon regrets his acts against Charlemagne, whereas Achilles remains unrelenting for a long time. ${ }^{108}$ The parallel can, however, even be extended. For, as said above, Fierabras is only the second part of a diptych. The first part of the diptych is formed by La destructioun de Rome, a short epic of about 1'500 lines, which tells of the Saracens' attack on Rome. ${ }^{109}$ But in its last lines the epic already tells of the events in Spain, briefly recounting not only the first battle in Spain but also the argument between Charlemagne and Roland, that led to the latter's withdrawal. ${ }^{110}$ So there is an overlap between La destructioun and Fierabras,

${ }^{100}$ Fierabras, v. 182 f. (Le Person, 2012, p. 276); Hom. Il. 1,327 and 1,331 f.

${ }^{101}$ Fierabras, v. 184-186 (Le Person, 2012, p. 276); Hom. Il. 1,300-303.

${ }^{102}$ Fierabras, v. 187-189 (Le Person, 2012, p. 276: the wise knight Ogier blames Roland) and v. 199

f. (Le Person, 2012, p. 277: the elderly counsellor Naimes tries to soothe Charlemagne); Hom. Il. 1,247-284 (Nestor acts as a mediator).

${ }^{103}$ Fierabras, v. 191-198 (Le Person, 2012, p. 276 f.: «Charles voit son neveu se mettre en fureur et se courroucer ... S'il en eut de la peine, il ne faut pas le demander ...»); Hom. Il. 1,285-291 and 1,318-326.

${ }^{104}$ Fierabras, v. 265-269 (Le Person, 2012, p. 279); Hom. Il. 1,488-492.

${ }^{105}$ Fierabras, v. 846-852 (Le Person, 2012, p. 306); Hom. Il. 11,599-601 and 18,1-14.

${ }^{106}$ Fierabras, v. 1803-1805 (Le Person, 2012, p. 359) and v. 1835-1840 (Le Person, 2012, p. 361); Hom. Il. 18,203-231.

${ }^{107}$ Fierabras, v. 1872-1874 (Le Person, 2012, p. 362); Hom. Il. 18,88-93 and 19,205-214.

${ }^{108}$ For Roland repenting see especially Fierabras, v. 265-267 (Le Person, 2012, p. 279) and the other comparable passages discussed by Drzewicka, 1992, p. 242-245. There are therefore no embassies to the sulking hero in Fierabras and there is never a formal reconciliation between king and hero.

${ }^{109}$ La destructioun de Rome will be quoted after the line-numbers and the text in J. Speich's bilingual (Old French / Modern French) edition (Speich, 1988).

${ }^{110}$ La destructioun de Rome, v. 1498-1501 (Speich, 1988, p. 167: “Quand il avait soupé [sc. Charlemagne], il commença à se vanter et dit que les vieillards barbus qu'il avait emmenés, s'étaient beaucoup mieux battus pendant la journée que les jeunes. A ces mots, Roland et le comte Olivier se fâchèrent.”). See the corresponding part in Fierabras, v. 38 f. (Le Person, 2012, p. 267: "Une fois revenu au camp, Roland fut honteusement raillé cette nuit-là.”) and the later flash-back by Roland himself in v. 158b-163 (Le Person, 2012, p. 275: "Lorsque nous fûmes de retour au camp, vous vous êtes vanté ensuite le soir, quand vous vous fûtes enivré, que les vieux chevaliers que vous aviez amenés avaient bien mieux 
the second epic resuming the last part of the first one. Exactly the same kind of overlap, however, can be observed between the Cypria and the Iliad. For in its last part the Cypria, the epic immediately preceding the Iliad, according to Proclus, had already told of Achilles' wrath, ${ }^{111}$ and precisely this will be the beginning of the Iliad, too.

Fierabras, an anonymous poem from about $1190 \mathrm{AD},{ }^{112}$ thus with La destructioun received a prologue, which was clearly intended to prepare for the events told in the older epic. ${ }^{113}$ It is, however, unclear, whether this binary distinction as shown by our texts reflects the origin and early history of the legend. From what we can still discern, it rather seems that in the early phases of the legend, there was no such distinction between a first part being located in Italy and a second part located in Spain. Instead, the whole action took place in Rome with the duel between Olivier and Fierabras as the culminating point of the story. This in any event is the situation in the Chronique rimée by Philippe Mousket, an Old French rhymed chronicle written around the year $1250,{ }^{114}$ probably based on a somewhat fuller treatment in an old (lost) cantilena, which itself went back to historical events having taken place in Rome. ${ }^{115}$ During the course of time this story was enlarged and significant parts of it were transferred to Spain, perhaps by the composer of Fierabras only, but more probably so by some predecessor. ${ }^{116}$ Transferring the duel from Rome to Spain, the composer of this version must have felt the need to explain afresh, why it was Olivier and not Roland, the tragic hero of Roncevaux, who engaged in the duel with Fierabras, and that in turn must have been the reason, why he introduced the argument between Charlemagne and Roland, which explains Roland's abstention from fighting. What had been one unified story, thus became a diptych of two epics, the second one starting with the quarrel between king and hero, just as the Iliad does.

combattu que les jeunes, et de beaucoup! Ce soir-là, nombreuses furent les railleries et les moqueries dont je fus l'objet! Mais par l'âme de mon père, c'est pour votre malheur que vous vous êtes vanté!’).

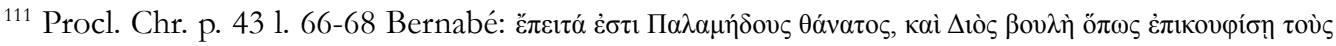

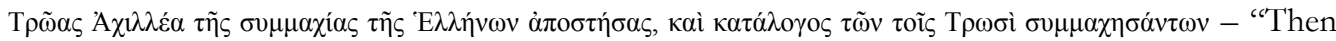
comes the death of Palamedes; and Zeus' plan to relieve the Trojans by removing Achilles from the Greek alliance; and a catalog of the Trojans' allies.” (transl. West, 2003, p. 81).

${ }^{112}$ For the date of Fierabras see Le Person, 2003, p. 142-144.

${ }^{113}$ For the date of La destructioun see Speich, 1988, p. 73 f., who proposes a date in the first half of the thirteenth century. The poem in its first lines is attributed to a certain Gautier de Douai, but it is unclear whether this is the composer of an earlier version or only a venerable name given to the poem (Speich, 1988, p. 74 f.).

${ }^{114}$ Philippe Mousket, Chronique rimée, v. 4664-4717 (edited by de Reiffenberg, 1836, p. 187-190 and Le Person, 2003, p. 145-147). This version with the duel taking place in Rome is confirmed by an erratic detail in Fierabras, v. 1098 f. (Le Person, 2012, p. 323, with the explanation in n. 132).

${ }^{115}$ In opposition to that, there is no clearly identifiable historical background for the events taking place in Spain; cf. Jauss, 1978, p. 318 f. and Le Person, 2003, p. 128.

${ }^{116}$ See the detailed discussions of the development of the story by de Mandach, 1987, p. 79-93; Speich, 1988, p. 7-12 and 18-20 and Le Person, 2003, p. 144-152. 
The question, of course, arises, where the composer of this version got this motif from. As in the case of Waltharius, there is, of course, an a limine probability that the motif might be derived from Latin sources, which themselves depend on the Iliad, especially from the Ilias Latina, which gives a picturesque description of Achilles drawing his sword against Agamemnon, paralleled, as we have seen, by Roland acting against Charlemagne. ${ }^{117}$ But other motifs that Fierabras has in common with the Iliad, like the hero threatening to slay whoever dares to touch him or a wise elderly person trying to mediate between the king and the hero, ${ }^{118}$ are absent from the Ilias Latina. So the Latin epic cannot have been the source for our poet, and as in the case of Waltharius, it must be said again that the legend of the Trojan War, if it was taken account of at all in medieval France, was studied via the novels of Dictys and Dares. This can even be proven in the case of Fierabras. For a remark about a cloak made by a fairy at Colchis gives rise to a short digression which tells of the Argonaut Jason who had gone there in order to get the golden fleece, an event, that, according to an extra-line in the most prominent manuscript of Fierabras, led to the destruction of Troy. ${ }^{119}$ This looks like bizarre mythology, but it is in fact only the sequence of events we find in Dares' Acta diurna. ${ }^{120}$

A second option - discussed above for the case of Rainouart - would be a reintegration of literary motifs into the oral world of story-telling. This might be seen as relatively plausible in this case, because the Iliad was a most prominent text known by semiliterate persons, too. But such a process, if it happened, would have to have happened in the Greek east, and then it would be difficult to answer, why there is only one such version with these Iliadic motifs in medieval France, but no trace of it in Byzantium or in the medieval and early modern world of the Slavs or the Germanic nations. Moreover, there is an excellent parallel for the motif of the hero drawing his sword against his king and of a third person preventing him from murder in the old Indian epic Mahabharata. Here it is the hero Arjuna, who has been offended by his elder brother and king Yudhishthira and draws his sword against him, but is stopped by his cousin Krishna. ${ }^{121}$ So, if we assume that the beginning of Fierabras depends on an oral popular version of the Iliad, we would have to assume the same for the analogous scene in the Mahabharata. But again, there is no trace for such a migration of the Homeric epics to India at the relevant time, that withstood scrutiny. ${ }^{122}$

\footnotetext{
${ }^{117}$ Ilias Latina, v. 74-80; Fierabras, v. 172 (Le Person, 2012, p. 275).

118 Above nn. 101 and 102.

${ }^{119}$ Fierabras, v. 2132-2136 (Le Person, 2012, p. 378: “...; cela causa ensuite la destruction de Troie, la grande cité.").

${ }^{120}$ Dares, ch. 1-2 and 6-44; see Ailes, 1994/1995, p. 252, who suggests (with some hesitation) that the immediate source might have been Benoît de Sainte-Maure's Roman de Troie (above n. 34).

${ }^{121}$ Mababharata 8,49 (= 8,69): “Thus addressed by Yudhishthira, Kunti’s son (sc. Arjuna) owning white steeds, filled with rage, drew his sword for slaying that bull of Bharata's race. Beholding his wrath, Kesava (sc. Krishna, an incarnation of the god Vishnu), conversant with the workings of the (human) heart said: 'Why, O Partha, dost thou draw thy sword?"' (transl. Ganguli, 1974, p. 176); see the discussion of this parallel between the Iliad and the Mahabharata by von Simson, 1984, p. 216. ${ }^{122}$ See the discussion in Grossardt, 2009, p. 50 f. and 98 (with n. 42).
} 
The correct answer to our question of how to explain the parallel of Fierabras with the Iliad presumably lies in the character of Roland as drawn in the medieval French tradition. Roland is always shown as a hotheaded, impetuous character easily losing his temper. The first example for such a character-drawing can already be found in the beginning of the Chanson de Roland, where his friend Olivier in a gathering of the French peers at Charlemagne's court dissuades Roland from going to Saragossa as an ambassador, because he is too ill-tempered. ${ }^{123}$ Another story still closer to our scene in Fierabras is told in the above-mentioned Chronique rimée by Philippe Mousket (v. 4586-4633), ${ }^{124}$ where Roland, while besieging the Saracens at Grenoble, out of anger refuses to help Charlemagne who is himself besieged by the Saracens in a fortress near Worms, and only after a while gets reconciled again. ${ }^{125}$ Such scenes must therefore have been common in French lore, and if we remind ourselves that the Charroi de Nimes begins with a similar scene of an argument between a king and his hero and ends like the Iliad (with its extension in the following Cyclic epics) and the Geste de Fierabras with the seizing of a town, we recognize that such patterns must have been traditional in France as well as in Greece. We may therefore conclude that this very device of starting an (oral) epic with a quarrel between a king and his most valiant champion was not an invention of the poet of the Iliad but an old circulating story-pattern either inherited by both nations from an old Indo-European legacy ${ }^{126}$ or transferred from one (Indo-European) nation to another through oral channels at a very early time. ${ }^{127}$ Horace's famous in medias res (Arspoetica, v. 148) was not the radical innovation the Roman poet credits his Greek forerunner with, but a traditional device masterly treated by Homer, but having been used already in a not so different way by many of his predecessors. No wonder that some of his later colleagues from other nations like the anonymous poet of the Geste de Fierabras made full use of it, too.

\section{Conclusion}

It cannot be denied that much of what has been said above is hypothetical, ${ }^{128}$ and further research especially with respect to the origin and diffusion of the motif of wrath

\footnotetext{
${ }^{123}$ Chanson de Roland, v. 255-258 («Sûrement pas, fit le comte Olivier; votre cœur est violent et farouche...» [transl. Dufournet, 1993, p. 81]).

${ }^{124}$ Edited by de Reiffenberg, 1836, p. 184-186.

${ }^{125}$ Interestingly, in this story Roland seems as torn between his wrath and his feelings of remorse (v. 4610-4615) as he is in Fierabras (above n. 108). The two stories, thus, clearly belong to the same tradition, and it would be an urgent task to assess the priority between them.

${ }^{126}$ In the case of the medieval French society this would mean that the story-pattern was inherited from the Celtic or the Germanic forefathers.

${ }^{127}$ Such an approach for explaining the linguistic and cultural analogies between the various IndoEuropean nations has been favoured by Vielle, 1996, IX-XI. In any event, the Song of Waltharius discussed above proves that comparable motifs were present in early medieval Europe already before the time of the chansons de geste and then could easily be transmitted to neighbouring nations.

${ }^{128}$ But then, much of what has been said in scholarship as an alternative like the idea of a traditionally chronographic epic transcended by Homer only, at a closer look, had been no less hypothetical.
} 
and withdrawal in the French epic tradition will certainly be needed. Some preliminary conclusions should nevertheless be possible.

A first point that becomes increasingly clear is that the motif of wrath and withdrawal is always tied to major heroes. This is, of course, the case for Achilles and for other well known heroes like Rostam in Iran, Karna in India and Marko Kraljević in Serbia, but now the observation can be extended to heroes like Hagen - after all one of the main heroes of the Song of the Nibelungen - and Roland, nephew of Charlemagne. A second point closely tied to the first one would be that normally in these stories the dispute between the king and his sulking hero cannot be settled quickly, but that it always takes some time and some embassies or speeches in order to reach a state of reconciliation. During this time a friend of the hero may act as his substitute and he may be seriously endangered and gravely wounded or even be killed. Minor heroes who react with anger for a short moment and are quickly reconciled can be found in the Homeric tradition only. ${ }^{129}$ Therefore, this may well have been a typescene, but only in the Greek epic tradition. The normal situation is rather what we find with respect to Achilles in the Iliad, that is, a boycott of a major hero endangering a whole military campaign. This may still be treated by a poet in a relatively episodic way as in the case of Achilles' argument with Agamemnon in the Cypria ${ }^{130}$ Rostam's abstention in the Shabnama or Hagano's withdrawal in the Song of Waltharius. But it is only natural that sometimes poets decided to give it more emphasis, that is, that they made it the focus point of their songs or even started their songs right with the argument between a king and his hero. This can be observed in a still relatively lose way in the song of Marko Kraljevic and Mina of Kostur and in the quarrel between Charlemagne and Roland that must lie behind the entry in Philippe Mousket's Chronique rimée (v. 4586-4633). But it can be found in the more tightened style of Horace's in medias res in at least two mutually independent songs, that is, in the Iliad and in the Geste de Fierabras. It is indeed the bipartite structure of the respective diptych Destructioun de Rome - Geste de Fierabras and Cypria - Iliad with the same cut immediately before the outbreak of the quarrel between king and hero (and an anticipation of the motif right at the end of the prior epic), which strongly speaks in favour of the assumption that the device to begin an epic song with the very motif of the quarrel was indeed a traditional one.

The examples for the motif of wrath and withdrawal we discussed so far all come from the Indo-European realm. It therefore must have appealed to the Indo-European nations and have resonated somehow with their specific mentality. So they transmitted it either vertically from an older common period to the single Indo-European nations or

${ }^{129}$ Hom. Il. 6,321-368 (Paris), 13,83-135 (some minor Greek heroes), 13,455-469 (Aeneas); see the discussion in Grossardt, 2001, p. 24-36 and 2009, p. 58-60.

${ }^{130}$ This episode, too, due the parallel of Rainouart and Guillaume in the Chanson de Guillaume, can now be classified as traditional. There is, therefore, no need to postulate a transfer of motifs within the Greek tradition from one episode involving an angered Achilles to the other (as had been done e.g. by Severyns, 1928, p. 304 [transference from the Iliad to the Cypria] or by Heubeck, 1950, p. 33 f. [= Heubeck, 1991, p. 470 f.: transference from the Cypria to the Iliad]). Instead, both incidents were traditional and mutually independent (see already, on more general grounds, Grossardt, 2009, p. 61 f.). 
horizontally from one nation to the other. But it should not be assumed that the motif can be found exclusively in Indo-European nations. There are indeed some rather clear examples in the Near Eastern area, too. Perhaps the oldest attested myth of this kind is the Middle Hittite story of the god of vegetation Telipinu, ${ }^{131}$ who got into a rage, therefore disappeared from the community of the gods and caused a standstill of nature and a general famine. ${ }^{132} \mathrm{It}$ took an embassy of a bee and ritual measures of another divine being, the goddess of magic Kamrušepa, in order to soothe Telipinu and to bring him back to the community of gods. ${ }^{133}$ A comparable Egyptian myth can be found in late inscriptions, in a demotic papyrus and in a Greek translation equally on papyrus. ${ }^{134}$ It tells the story of the Egyptian goddess Tefnut, the daughter of the sun-god Re, who out of anger left Egypt for Ethiopia and was brought back to Egypt by the messenger-god Thot, only after long and difficult negotiations. ${ }^{135}$ Several early witnesses like an ostrakon of about 1200 BC showing Tefnut and Thot on their way back to Egypt point to a rather early date of the myth. ${ }^{136}$ In the Old Testament, finally, what stands out, is the story of Job who had been stricken for no apparent reasons by several plagues and therefore refused to listen to a group of three friends who came to him and tried to reconcile him with the Lord through a series of speeches. It was only a much younger fourth person and finally God himself who with their speeches managed to reach a new union with Job. ${ }^{137}$ But there are minor parallels, too, which have been pointed out by the classical scholar Franz Dornseiff. 138

Future research should therefore try to relate these Near Eastern examples to the Indo-European ones and study in some detail their similarities as well as their differences. But the most promising area will probably remain Homer and the legend of the Trojan War at large. For what becomes increasingly clear - at least to the mind of the present writer - is that the classic assumption of a chronographic form of the tradition with an equal focus on all episodes of the War is now outdated. It was not a steady chronographic legend which by some genius was transformed into an epic of more focused and dramatic form, but it were

${ }^{131}$ So admittedly from an Indo-European nation, whose traditional lore, however, was heavily influenced by neighbouring Semitic nations.

${ }^{132}$ The myth has been translated into English by A. Goetze (in Pritchard, 1969, p. 126-128); a German version, reflecting current research, can be found in Janowski, Schwemer, 2015, p. 155-160 (translated by a team of scholars consisting of A. Bauer, S. Görke, J. Lorenz and E. Rieken).

${ }^{133}$ The myth has been further discussed and compared to the Homeric Hymn to Demeter by Considine, 1969, p. 116 f. and Cheyns, 1988, p. 45 f.

${ }^{134}$ See the respective editions and translations by Junker, 1917, by Spiegelberg, 1917 and de Cenival, 1988, and by Reitzenstein, 1923 and St. West, 1969.

${ }^{135}$ See the summary of the myth by Spiegelberg, 1915, p. 880-887 and 1917, 4-7.

${ }^{136}$ Spiegelberg, 1917, p. 7-9; de Cenival, 1988, IX.

${ }^{137}$ Old Testament, Book of Job; see the comparison of the biblical story with the story of Achilles and Agamemnon by Louden, 2006, p. 179-182.

${ }^{138}$ Dornseiff, 1956, p. 10-17, pointing to various parallels between the Iliad and the First and Second Book of Samuel. The parallels are not always very cogent, but what might be added, are the three failed embassies from Saul to David in 1 Sam. 19,19-21; see further Louden, 2006, p. 161-163. 
such dramatic episodes as the quarrel between Achilles and Agamemnon which gave rise to a full treatment of the legend with many single episodes. Such kernels of the legend, around which smaller episodes crystallized, were, next to the quarrel, the story of the conquest of the town with the help of the Trojan Horse and the homecoming of Odysseus. ${ }^{139}$ How exactly this happened, will always remain difficult to elucidate, but perhaps in this respect, too, the comparative approach might turn out to be promising. ${ }^{140}$

\section{REFERENCES}

ADLER, Alfred. Rainouart and the composition of the Chanson de Guillaume. Modern Pbilology, v. 49, p. 160-171, 1951/1952.

ADLER, Alfred. Rück zug in epischer Parade. Studien zu Les quatre fils Aymon, La chevalerie Ogier de Danemarche, Garin le Loherenc, Raoul de Cambrai, Aliscans, Huon de Bordeaux. Frankfurt am Main: Klostermann, 1963.

AILES, Marianne J. Fierabras and the Chanson de Roland: an intertextual diptych. Reading Medieval Studies, v. 28, p. 3-22, 2002.

AILES, Marianne J. The date of the chanson de geste Fierabras. Olifant, v. 19, p. 245-271, 1994/1995.

ALONSO, Dámaso. La primitiva épica francesa a la luz de una nota emilianense. In:

Primavera temprana de la literatura europea. Lírica - epica - novela. Madrid: Guadarrama, 1961, p. 81-161.

BENDER, Karl-Heinz. König und Vasall. Untersuchungen zur Chanson de geste des XII. Jabrbunderts. Heidelberg: Winter, 1967.

BISANTI, Armando. Il Waltharius fra tradizioni classiche e suggestioni germaniche. PanRivista di Filologia Latina, v. 20, p. 175-204, 2002.

BLÄNSDORF, Jürgen. Selbstbehauptung und Pflichtenkonflikt im „Waltharius“. In: MEISIG, Konrad (Ed.). Rubm und Unsterblichkeit. Heldenepik im Kulturvergleich. Wiesbaden: Harrassowitz, 2010, p. 75-92.

\footnotetext{
${ }^{139}$ The traditionality of the device to focus on the very episode of the Trojan Horse is shown by the parallel between the song of Demodocus (as told in $O d .8,499-520$ ) and the Iliupersis (according to the summary in Proclus); see West, 2003, p. 16 and 2013, p. 19. The traditional shape of the Odyssey is demonstrated by many other tales of homecoming with a similar design (above n. 5).

${ }^{140}$ A promising field for such an enterprise might be a comparison of the Cyclic epics Aithiopis and Little Iliad with book six of the Indian national epic Ramayana, because in each case it is a large number of minor episodes - usually triggered by the foregrounding of a certain hero on either side or by the arrival of a new helper to one of the two warring parties from outside - which follows the more compact and colourful action treated in the preceding epic resp. book.
} 
BOOR, Helmut de. Das Nibelungenlied. Zweisprachig, herausgegeben und übertragen von $\mathrm{H}$. de Boor. 5th ed. Köln: Parkland, 2003.

BORNHOLDT, Claudia. Engaging moments: the origins of medieval bridal-quest narrative. Berlin: de Gruyter, 2005.

BOUTET, Dominique. La perspective indo-européenne et les études médiévales. In: VALETTE, Jean-René (Ed.). Trente ans de recherches en langues et en littératures médiévales (= Perspectives médiévales, special edition for the 30th anniversary of the periodical). Paris: Société de Langues et de Littératures Médiévales d'Oc et d'Oïl, 2005, p. 99-114.

BOUTET, Dominique. The chanson de geste and orality. In: REICHL, Karl (Ed.). Medieval oral literature. Berlin: de Gruyter, 2012, p. 353-369.

BURKERT, Walter. Structure and history in Greek mythology and ritual. Berkeley: University of California Press, 1979.

CALIN, William C. The Old French epic of revolt. Raoul de Cambrai, Renaud de Montauban, Gormond et Isembard. Genève: Droz, 1962.

CENIVAL, Françoise de. Le mythe de l'ail du soleil. Sommerhausen: Zauzich, 1988.

CHADWICK, Nora Kershaw. Russian heroic poetry. Cambridge: Cambridge University Press, 1932.

CHEYNS, André. La structure du récit dans l'Iliade et l'Hymne homérique à Déméter. Revue Belge de Philologie et d'Histoire, v. 66, p. 32-67, 1988.

CHIBNALL, M. The ecclesiastical history of Orderic Vitalis. Edited and translated by M. Chibnall. Oxford: Clarendon Press, 1972. v. 3: books V and VI.

COLBY-HALL, Alice M. In search of the lost epics of the lower Rhône valley. Olifant, v. 8, p. 339-351, 1980/1981.

CONSIDINE, Patrick. The theme of divine wrath in ancient East Mediterranean literature. Studi Micenei ed Egeo-Anatolici, v. 8, p. 85-159, 1969.

DANEK, Georg. Die Apologoi der Odyssee und ,Apologoi‘ im serbokroatischen Heimkehrerlied. Wiener Studien, v. 109, p. 5-30, 1996.

DORNSEIFF, Franz. Homeros. In: . Antike und alter Orient. Interpretationen. Leipzig: Koehler \& Amelang, 1956, p. 1-23.

DRZEWICKA, Anna. Le preux et le sage reflétés par un miroir déformant. Roland et Olivier dans Fierabras. Cultura Neolatina, v. 52, p. 231-245, 1992.

DUFOURNET, J. La Chanson de Roland. Texte présenté, traduit et commenté par J. Dufournet. Paris: Flammarion, 1993. 
EDWARDS, Mark W. Homer's Iliad. In: FOLEY, John Miles (Ed.). A companion to ancient epic. Malden: Blackwell, 2005, p. 302-314.

ERBSE, Hartmut. Ilias und ,Patroklie‘. Hermes, v. 111, p. 1-15, 1983.

FAGLES, R. Homer. The Iliad. Translated by R. Fagles, introduction and notes by B. Knox. New York: Viking, 1990.

FARAL, E. Ermold le Noir. Poème sur Lonis le Pieux et épitres au roi Pépin. Édités et traduits par Edmond Faral. Paris: Champion, 1932.

FASBENDER, Christoph. Waltharius In: ACHNITZ, Wolfgang (Ed.). Deutsches LiteraturLexikon - Das Mittelalter. Band 5: Epik (Vers - Strophe - Prosa) und Kleinformen. Berlin: de Gruyter, 2013, p. 10-15.

FASSÒ, Andrea. Le petit cycle de Guillaume et les trois péchés du guerrier. In: (Ed.). La chanson de geste e il ciclo di Guglielmo d'Orange (= Medioevo Romanzo, v. 21, 1997, p. 161-529). Roma: Salerno, 1997, p. 421-440.

FRAPPIER, Jean. Les chansons de geste du cycle de Guillaume d'Orange I. - La Chanson de Guillaume, Aliscans, La Chevalerie Vivien. Paris: Soc. d'Éd. d'Enseignement Supérieur, 1955.

FRAPPIER, Jean. Les chansons de geste du cycle de Guillaume d'Orange II. - Le Couronnement de Louis, Le Charroi de Nîmes, La Prise d'Orange. 2e. ed. Paris: Soc. d'Éd. d'Enseignement Supérieur, 1967.

GALMÉS DE FUENTES, Alvaro. Le 'Charroi de Nîmes' et la tradition arabe. Cabiers de Civilisation Médiévale, v. 22, p. 125-137, 1979.

GANGULI, Kisari Mohan. The Mahabharata of Krishna-Dwaipayana Vyasa. Translated into English prose from the original Sanskrit text by K. M. Ganguli. 3rd ed. New Delhi: Munshiram Manoharlal, 1974. v. 7.

GÖHLER, Peter. Beobachtungen und Überlegungen zu den Fragmenten einer mittelhochdeutschen Walther- und Hildegundsdichtung. In: ZATLOUKAL, Klaus (Ed.). 7. Pöchlarner Heldenliedgespräch. Mittelhochdeutsche Heldendichtung außerbalb des Nibelungen- und Dietrichkreises (Kudrun, Ortnit, Waltharius, Wolfdietriche). Wien: Fassbaender, p. 91-108, 2003.

GRIFFIN, Jasper. Homer. Oxford: Oxford University Press, 1980 (= Bristol 22001, with different pagination).

GRIFFIN, Jasper. Homer, Iliad, book nine. Oxford: Oxford University Press, 1995.

GRISWARD, Joël H. Epopée indo-européenne et épopée médiévale: histoires ou histoire?. Perspectives Médiévales, v. 8, p. 125-134, 1982.

GRISWARD, Joël H. La naissance du couple littéraire Vivien et Rainouart. In: FASSÒ, Andrea (Ed.). La chanson de geste $e$ il ciclo di Guglielmo d'Orange (= Medioevo Romanzo, v. 21, 1997, p. 161-529). Roma: Salerno, 1997, p. 441-456. 
GRISWARD, Joël H. Le thème de la révolte dans les chansons de geste: éléments pour une typologie du héros révolté. In: BENNETT, Philip E.; COBBY, Anne Elizabeth; RUNNALLS, Graham A. (Ed.). Charlemagne in the North. Proceedings of the twelfth International Conference of the Société Rencesvals (Edinburgh 1991). Edinburgh: Grand and Cutler, 1993, p. 399-416.

GROSSARDT, Peter. Achilleus, Coriolan und ihre Weggefährten. Ein Plädoyer für eine Behandlung des Acbilleus-Zorns aus Sicht der vergleichenden Epenforschung. Tübingen: Narr, 2009.

GROSSARDT, Peter. Die Erzäblung von Meleagros. Zur literarischen Entwicklung der kalydonischen Kultlegende. Leiden: Brill, 2001.

GROSSARDT, Peter. Noch einmal zum Heldenzorn bei Marko Kraljević und Achilleus. Hermes, v. 143, p. 229-239, 2015.

HANSEN, William F. Ariadne's thread: a guide to international tales found in classical literature. Ithaca: Cornell University Press, 2002.

HANSEN, William F. Folktale. In: FINKELBERG, M. (Ed.). The Homer encyclopedia. Malden: Blackwell, 2011, v. 1, p. 291-293.

HAUG, Vollmann. Frühe deutsche Literatur und lateinische Literatur in Deutschland 8001150. Herausgegeben von Walter Haug und Benedikt Konrad Vollmann. Frankfurt am Main: Deutscher Klassiker, 1991.

HAUG, Walter. Von der Schwierigkeit heimzukehren. Die Walthersage in ihrem motivgeschichtlichen und literaturanthropologischen Kontext. In: KRAUSE, Burkhardt (Ed.). Verstehen durch Vernunft. Festschrift für Werner Hoffmann. Wien: Fassbaender, p. 129-144, 1997.

HEINTZE, Michael. König, Held und Sippe. Untersuchungen zur Chanson de geste des 13. und 14. Jahrbunderts und ibrer Zyklenbildung. Heidelberg: Winter, 1991.

HEUBECK, Alfred. Die homerische Frage. Ein Bericht über die Forscbung der letzten Jahrze hnte. Darmstadt: Wissenschaftliche Buchgesellschaft, 1974.

HEUBECK, Alfred. Studien zur Struktur der Ilias (Retardation - Motivübertragung). In: Gymnasium Fridericianum. Festschrift zur Feier des 200-jäbrigen Bestehens des Humanistischen Gymnasiums Erlangen 1745-1945. Teil II. Erlangen: Döres, 1950, p. 17-36 (reprinted in: LATACZ, Joachim [ed.]. Homer. Die Dichtung und ibre Deutung. Darmstadt: Wissenschaftliche Buchgesellschaft, 1991, p. 450-474).

HIMES, Jonathan B. The Old English Epic of Waldere. Edited and translated with an introduction by J. B. Himes. Newcastle upon Tyne: Cambridge Scholars, 2009.

HOGGAN, David G. La formation du noyau cyclique: Couronnement de Louis - Charroi de Nîmes - Prise d'Orange. In: SOCIETE Rencesvals. Actes du $5^{\mathrm{e}}$ Congrès International de la Société Rencesvals (Oxford 1970). Salford: University of Salford, 1977, p. $22-44$. 
ON THE HOMERIC QUESTION - SOME PRELIMINARY REMARKS

HÖLSCHER, Uvo. Die Odyssee. Epos zwischen Märchen und Roman. 2nd. ed. München: Beck, 1989.

HUNT, Tony. L'inspiration idéologique du Charroi de Nîmes. Revue Belge de Philologie et d'Histoire, v. 56, p. 580-606, 1978.

JANDA, Michael. Der Zorn des Achilleus. Münster: Thomas Kubo, 2018.

JANOWSKI, Bernd; SCHWEMER, Daniel (Ed.). Texte aus der Umwelt des Alten Testaments. Neue Folge. Band 8: Weisheitstexte, Mythen und Epen. Gütersloh: Gütersloher Verlagshaus, 2015.

JAUSS, Hans Robert. Epos und Roman - Eine vergleichende Betrachtung an Texten des XII. Jahrhunderts (Fierabras - Bel Inconnu). In: KRAUSS, Henning (Ed.). Altfranzösische Epik. Darmstadt: Wissenschaftliche Buchgesellschaft, 1978, p. 314-337.

JUNKER, Hermann. Die Onurislegende. In: Denkschriften der Kaiserlichen Akademie der Wissenschaften in Wien. Philosophisch-historische Klasse. 59. Band, 1. und 2. Abhandlung. Wien: A. Hölder, 1917.

KAKRIDIS, Johannes Th. Homeric researches. Lund: Gleerup, 1949.

KELLER, Hans-Erich. La belle Sarrasine dans Fierabras et ses dérivés. In: BENNETT, Philip E.; COBBY, Anne Elizabeth; RUNNALLS, Graham A. (Ed.). Charlemagne in the North. Proceedings of the Twelfth International Conference of the Societe Rencesvals (Edinburgh 1991). Edinburgh: Grand and Cutler, 1993, p. 299-307.

KULLMANN, Wolfgang. Zur Methode der Neoanalyse in der Homerforschung. Wiener Studien, N.F. v. 15, p. 5-42, 1981.

LACHET, Claude. La prise d'Orange. Chanson de geste (fin XII - début XIII e siècle). Édition bilingue, texte établi, traduction, présentation et notes par C. Lachet. Paris: Champion, 2010. LACHET, Claude. Le charroi de Nîmes. Chanson de geste du Cycle de Guillaume d'Orange. Édition bilingue, présentée et commentée par C. Lachet. Paris: Gallimard, 1999.

LANGLOIS, Ernest. Le couronnement de Louis. Chanson de geste du XII siècle. Éditée par E. Langlois. $2^{\mathrm{e}}$ ed. Paris: Champion, 1925.

LANLY, André. Le couronnement de Louis. Chanson de geste du XII siècle. Traduite par A. Lanly. Paris: Champion, 1983.

LATACZ, Joachim. Homer. Eine Einführung. München-Zürich: Artemis, 1985.

LEARNED, Marion Dexter. The saga of Walther of Aquitaine. Baltimore: Modern Language Association of America, 1892.

LEJEUNE, Rita. La naissance du couple littéraire "Guillaume d'Orange et Rainouard au Tinel". Marche Romane, v. 20, p. 39-60, 1970.

LE PERSON, Marc. Fierabras. Chanson de geste du XIIe siècle. Éditée par M. Le Person. Paris: Champion, 2003. 
LE PERSON, Marc. Fierabras. Chanson de geste du XII siècle. Traduction en français moderne du texte du manuscrit E. Traduction, présentation, bibliographie et notes par M. Le Person. Paris: Champion, 2012.

LIENERT, Elisabeth. Mittelhochdentsche Heldenepik. Eine Einführung. Berlin: Schmidt, 2015.

LORD, Albert Bates. The effect of the Turkish conquest on Balkan epic tradition. In: BIRNBAUM, Henrik; VRYONIS, Speros (Ed.). Aspects of the Balkans. Continuity and change. The Hague-Paris: Mouton, 1972, p. 298-318.

LORD, Albert Bates. The theme of the withdrawn hero in Serbo-Croatian oral epic. Prilozi za književnost, jezik, istoriju ifolklor, v. 35, p. 18-30, 1969.

LOUDEN, Bruce. The Iliad. Structure, myth, and meaning. Baltimore: Johns Hopkins University Press, 2006.

MABILLON, Joannes. Acta sanctorum ordinis Benedicti. Saeculum quartum. Pars prima. Edidit J. Mabillon. Venetiis: 1735.

MACLEAN, Simon. 'Waltharius': treasure, revenge and kingship in the Ottonian Wild West. In: GILBERT, Kate; WHITE, Stephen D. (Ed.). Emotion, violence and law in the Middle Ages. Essays in honour of William Ian Miller. Leiden: Brill, 2018, p. 225-251.

MAGOUN, Francis P.; SMYSER, Hamilton M. Walter of Aquitaine. Materials for the study of his legend. Translated by F. P. Magoun and H. M. Smyser. New London: Connecticut College, 1950.

MANDACH, André de. Naissance et développement de la chanson de geste en Europe V. La geste de Fierabras - Le jeu du réel et de l'invraisemblable, avec des textes inédits. Genève: Droz, 1987.

MCMILLAN, Duncan. Le Charroi de Nîmes. Chanson de geste du XII e siècle. Éditée d'après la rédaction AB, avec introduction, notes et glossaire, par D. McMillan. Paris: Klincksieck, 1972.

MILLET, Victor. Deconstructing the hero in early medieval heroic poetry. In: MILLET, Victor; SAHM, Heike (Ed.). Narration and hero. Recounting the deeds of heroes in literature and art of the early medieval period. Berlin: de Gruyter, 2014, p. 229-239.

MORA-LEBRUN, Francine. L'Enéide médiévale et la chanson de geste. Paris: Champion, 1994.

MUELLNER, Leonard. The anger of Acbilles. Menis in Greek epic. Ithaca: Cornell University Press, 1996.

NAGY, Gregory. The best of the Achaeans. Concepts of the hero in archaic Greek poetry. Baltimore: Johns Hopkins University Press, 1979 (2nd ed. 1999).

O'RAHILLY, Cecile. Táin Bó Cúalnge from the book of Leinster. Edited by C. O'Rahilly. Dublin: Dublin Institute for Advanced Studies, 1967.

OINAS, Felix J. Russian byliny. In: (Ed.). Heroic epic and saga. An introduction to the world's great folk epics. Bloomington: Indiana University Press, 1978, p. 236-256. 
PANZER, Friedrich. Der Kampf am Wasichenstein. Waltharius-Studien. Speyer: Historisches Museum der Pfalz zu Speyer, 1948.

POIRION, Daniel. Chanson de geste ou épopée? Remarques sur la définition d'un genre. Travaux de Linguistique et de Littérature, v. 10, n. 2, p. 7-20, 1972.

PRITCHARD, James B. Ancient Near Eastern texts relating to the Old Testament. Edited by J. B. Pritchard. Third edition with supplement. Princeton: Princeton University Press, 1969.

RATKOWITSCH, Christine. O vortex mundi, fames, insatiatus habendi, gurges avaritiae. Das Waltharius-Epos zwischen altgermanischem Sagenstoff, Vergils ,Aeneis ${ }^{6}$ und christlicher Moral. Mittellateinisches Jabrbuch, v. 51, p. 1-38, 2016.

REGENITER, Wolfgang. Sagenscbichtung und Sagenmiscbung. Untersuchungen zur Hagengestalt und zur Geschichte der Hilde- und Walthersage. München: Philosophische Fakultät, 1971.

REICHL, Karl. Fierabras. In: ENZYKLOPÄDIE des Märchens. Berlin: de Gruyter, 1984, v. 4, p. 1100-1102.

REIFFENBERG, Baron de. Chronique rimée de Philippe Mouskes. Publiée par le Baron de Reiffenberg. Bruxelles: Hayez, 1836. t. 1.

REINHARDT, Karl. Die Ilias und ibr Dichter. Herausgegeben von Uvo Hölscher. Göttingen: Vandenhoek \& Ruprecht, 1961.

REITZENSTEIN, Richard. Die griechische Tefnutlegende. Sitzungsberichte der Heidelberger Akademie der Wissenschaften, Philosophisch-historische Klasse, 1923,2. Heidelberg: Winter, 1923.

RING, Abram. Waltharius. Edition, translation, and introduction by A. Ring. Leuven: Peeters, 2016.

RIO, Alice. Waltharius at Fontenoy? Epic heroism and Carolingian political thought. Viator: Medieval and Renaissance Studies, v. 46, n. 2, p. 41-64, 2015.

SAUGE, André. Review of Grossardt 2009. In: http://bmcr.brynmawr.edu/2010/2010-02-28.html.

SCAFFAI, Marco. Baebii Italici Ilias Latina. Introduzione, edizione critica, traduzione italiana e commento a cura di M. Scaffai. 2nd ed. Bologna: Pàtron, 1997.

SCHNEIDER, Hermann. Das Epos von Walther und Hildegunde. Germanisch-Romanische Monatsscbrift, v. 13, p. 14-32 and 119-130, 1925.

SCHWAB, Ute. Nochmals zum ags. Waldere neben dem Waltharius. Beiträge zur Geschichte der Deutschen Sprache und Literatur, v. 101, p. 229-251 and 347-368, 1979.

SEVERYNS, Albert. Le cycle épique dans l'école d'Aristarque. Liége: Vaillant-Carmanne, 1928.

SIMSON, Georg von. The mythic background of the Mahabharata. Indologica Taurinensia, v. 12, p. 191-223, 1984. 
SMITH, Colin. Poema de mio Cid. Edited with introduction and notes by Colin Smith. Oxford: Clarendon Press, 1972.

SPEICH, Johann Heinrich. La Destructioun de Rome (d'après le ms. de Hanoure IV, 578). Bern: Peter Lang, 1988.

SPIELBERG, Wilhelm. Der ägyptische Mythus vom Sonnenauge in einem demotischen Papyrus der römischen Kaiserzeit. Sitzungsberichte der Königlich Preußischen Akademie der Wissenschaften, 1915, p. 876-894.

SPIELBERG, Wilhelm. Der ägyptische Mythus vom Sonnenauge nach dem Leidener demotischen Papyrus I 384. Strassburg: Strassburger Druckerei und Verlagsanstalt, 1917.

STRECKER, Karl. Die lateinischen Dichter des deutschen Mittelalters. Sechster Band: Nachträge zu den poetae aevi Carolini, Erster Teil (= Monumenta Germaniae Historica, Poetarum Latinorum Medii Aevi Tomus VI / Fasc. I). Mit Unterstützung von Otto Schumann herausgegeben von Karl Strecker. Weimar: Hermann Böhlaus Nachfolger, 1951.

STRECKER, Karl. Ekkehards Waltharius. Berlin: Weidmann, 1907.

SUARD, François. Guide de la chanson de geste et de sa postérité littéraire, (XIe-XVe siècle). Paris: Champion, 2011.

SUARD, François. La chanson de Guillaume. Texte établi, traduit et annoté par F. Suard. Paris: Librairie Générale Française, 2008.

THOMPSON, Stith. Motif-index of folk-literature. A classification of narrative elements in folk-tales, ballads, myths, fables, mediaeval romances, exempla, fabliaux, jest-books, and local legends. Revised and enlarged edition. Copenhagen: Rosenkilde and Bagger, 1955-1958. 6 v.

TRAUTMANN, Reinhold. Die Volksdichtung der Großrussen, I. Band. Das Heldenlied (die Byline). Heidelberg: Winter, 1935.

UTHER, Hans-Jörg. The types of international folktales: a classification and bibliography based on the system of Antti Aarne and Stith Thompson. Helsinki: Suomalainen Tiedeakatemia, Academia Scientiarum Fennica, 2004. 3 v.

VIELLE, Christophe. Le mytho-cycle héroïque dans l'aire indo-européenne. Correspondances et transformations helléno-aryennes. Louvain: Peeters, 1996.

VIELLIARD, Jeanne. Le guide du Pèlerin de Saint-Jacques de Compostelle. Texte latin du XIIe siècle, édité et traduit en français d'après les manuscrits de Compostelle et de Ripoll. Macon: Protat frères, 1938.

WATHELET-WILLEM, Jeanne. Les parents de Rainouart. Le Moyen Age. Revue d'Histoire et de Philologie, v. 83, p. 53-70, 1977.

WATHELET-WILLEM, Jeanne. Rainouart et son cycle. In: KRAUSS, Henning; RIEGER, Dietmar (Ed.). Mittelalterstudien Erich Köbler zum Gedenken. Heidelberg: Winter, 1984, p. 288300. 
WATHELET-WILLEM, Jeanne. Recherches sur la Chanson de Guillaume; Études accompagnées d'une édition. Paris: Belles Lettres, 1975. 2 v.

WEST, Martin L. Greek epicfragments from the seventh to the fifth centuries BC. Edited and translated by M. L. West. Cambridge, MA: Harvard University Press, 2003.

WEST, Martin L. The Epic Cycle: a commentary on the lost Troy epics. Oxford: Oxford University Press, 2013.

WEST, Stephanie. The Greek version of the legend of Tefnut. Journal of Egyptian Archaeology, v. 55, p. 161-183, 1969.

WILLIAMSON, Joan B. Le personnage de Rainouart dans la Chanson de Guillaume. In: BUSCHINGER, Danielle (Ed.). Guillaume et Willehalm. Les épopées françaises et l'auvre de Wolfram von Eschenbach. Göppingen: Kümmerle, 1985, p. 159-171.

WOLF, Kordula. Troja - Metamorphosen eines Mythos. Französische, englische und italienische Überlieferungen des 12. Jahrhunderts im Vergleich. Berlin: Akademie Verlag, 2009.

ZHIRMUNSKY, Viktor. Vergleichende Epenforschung I. Berlin: Akademie Verlag, 1961.

ZHIRMUNSKY, Viktor. Виктор Жирмунский, Народныци героический эпос. Сравнительноисторические очерки (Victor Zhirmunsky, Popular heroic epic: comparative-historical sketches, in Russian). Moscow-Leningrad: Гос. изА-во худож. мит-ры, 1962.

ZWIERLEIN, Otto. Das Waltharius-Epos und seine lateinischen Vorbilder. Antike und Abendland, v. 16, p. 153-184, 1970. 
